\title{
Assessment of Flash-Flood Hazard in Arid Watersheds of Jordan
}

\author{
Yahya Farhan'1, Atef Ayed ${ }^{2}$ \\ ${ }^{1}$ Retired Professor, Amman, Jordan \\ ${ }^{2}$ Geography Department, University of Jordan, Amman, Jordan \\ Email: wjetfan47962@gmail.com
}

How to cite this paper: Farhan, Y. and Ayed, A. (2017) Assessment of Flash-Flood Hazard in Arid Watersheds of Jordan. Journal of Geographic Information System, 9, 717-751.

https://doi.org/10.4236/jgis.2017.96045

Received: November 19, 2017

Accepted: December 25, 2017

Published: December 28, 2017

Copyright (c) 2017 by authors and Scientific Research Publishing Inc. This work is licensed under the Creative Commons Attribution International License (CC BY 4.0).

http://creativecommons.org/licenses/by/4.0/

(c) (i) Open Access

\begin{abstract}
Flash flood hazard initiated by heavy rainstorms is common in arid Jordan, and often has induced immense damage to life and infrastructures. The current study presents a flash flood assessment for Wadi Rajil (northern Jordan) and Wadi Wuheida (southern Jordan) watersheds using ASTER DEM, GIS, and geomorphic field observation. A total of 23 morphometric parameters of paramount relation to flash flood risk estimation were extracted and calculated using ASTER DEM, GIS, and mathematical formulae developed for this purpose. Two methods were employed to assess flash floods and to generate flooding risk susceptibility maps. The first method is El-Shamy's approach, and the second is the morphometric hazard degree assessment method. Consequently, sub-basins with high and extreme flooding susceptibility were demarcated and displayed spatially using GIS. The maps so produced are meant to help planners and decision makers to devise appropriate plans to mitigate harmful flooding impacts, and to deal with flooding hazards.
\end{abstract}

\section{Keywords}

Flash Flood, ASTER DEM, Morphometry, Arid Watersheds, El-Shamy's Approach, Jordan

\section{Introduction}

Morphometric analyses of drainage basins based on geoinformatics techniques and field collected data, are essential tools for flash floods hazard assessment. Relevant evaluation parameters can be employed to predict the hydrological behavior of the catchment, and geomorphic processes produced by exceptionally heavy rainstorms, and the resultant flash floods, including erosion type, rate, and sediment yield [1]. Hydromorphic explanation can be refined regarding the 
conditions of flash floods generation, their destructive impacts, initiation of landslides and gully erosion, and the provision of abundant sediment supply. When field data are incorporated with remote sensing and GIS, it will provide precise information on morphometric properties of sub-basins and flash floods, and can be employed to assess areas prone to flash flooding, estimating flooding risk, and delineating the most susceptibility zones for flooding hazard. Rapid generated flows are frequently assigned to "flash floods" which are defined as "sudden floods with high peak discharges, produced by severe thunder storms that are generally of limited areal extent" [2] [3] [4]. Although flood hazards are most common in humid regions, they are equally characteristic events in arid and semiarid regions in the form of flash floods [5]. Climatic conditions generating flash floods are common in arid Jordan, and they are initiated due to heavy rainstorms accompanied by high amount of precipitation falling in a short period of time. Thunder storms which produce flash floods are a localized process that takes place over the inland watersheds ranging in area from few kilometers to several hundred square $\mathrm{km}$. Flashfloods in arid Jordan are extremely dangerous and of disruptive nature. They frequently cause extensive property damage, loss of life, and slope instability due to severe gully erosion and slumping. Other factors encouraging flash floods in Jordan are the morphological and ecological setting of arid watersheds (i.e., the presence of long steep slopes, drainage networks, poor vegetation cover, low or negligible infiltration, and high velocity flows). In addition, human interventions render arid watershed highly vulnerable to flash flooding [6]. Past experience in arid coastal cities such as Aqaba and Eilat on the Gulf of Aqaba [7] [8] [9] [10] [11], Gulf of Suez, Red Sea and Sinai Peninsula [12] [13] [14] reveals that flash floods are classified as the most recurrent disaster recorded over the last three decades in the Middle East including Jordan. Available records of flash floods indicate that arid cities such as Aqaba, Ma'an, and Wadi Musa-Petra have been exposed to several flash floods of low magnitude (5 - 7 year return periods), medium magnitude (20 - 25 year return periods), and high magnitude (50 year return periods) [15] [16] [17] [18] [19] and caused immense damage to life and infrastructure. Moreover, unpredictable flash floods occasionally have caused serious problems to road networks located in mountain valleys (i.e., the Aqaba-Amman highway, Wadi Yutum, $15 \mathrm{~km}$ north of Aqaba), or on the desert plains (i.e., the Amman-Aqaba highway west of $\mathrm{Ma}$ 'an, the lower Wadi Wuheida), or the roads in Qa'a Azraq (lower WadiRajil). As an alternative to costly prolonged field monitoring of watersheds to assess flood hazards, remote sensing and GIS techniques combined with hydro-morphometric analysis of watersheds provide a rapid, low cost and efficient tool to map and determine areas vulnerable to flood hazards and level of risk. Based on available free access ASTER and SRTM DEM's of reasonable resolution, it is possible to extract and calculate morphometric basic, linear, areal, shape, and relief parameters [20]-[26]. In the present research, two arid watersheds: Wadi Rajil (northern Jordan) and Wadi Wuheida (southern Jordan) were investigated using topographic, geological maps, air photos, field inspec- 
tion, and ASTER DEM. Morphometric characterization and description of the hydrological pattern were conducted for both watersheds. The aim is also to generate flood hazards susceptibility maps based on El-Shamy's approach [27], and the morphometric hazard degree assessment method [28] [29] [30], in order to predict and demarcate the most hazardous sub-basins in terms of flooding, and the sub-basins which are expected to endanger Ma'an city, the Amman-Aqaba highway and Qa'a Azraq. The flood hazard maps produced were intended to help the planners understand the spatial distribution of flood hazard conditions, thus enabling them to prepare appropriate mitigation measures to reduce the negative impacts of flash floods. This research is also meant to improve the level of awareness among planners regarding flood geomorphology [31], and the essential role of morphometric analysis/information in the planning process [32] [33] [34] [35]. Moreover, attention is focused on providing advice for future planning on how to avoid destructive flood hazards in remote and data scarce areas. Appropriate measures for planning adjustment towards flooding hazards and management are recommended to help decision makers mitigate flash floods through the construction of flood prevention structures (i.e., surface water harvesting systems, and groundwater artificial recharge). The recommended measures are flexible to the extent that these can be carried out by local administrative officials and the residents.

\section{Study Area}

Wadi Wuheida is an ephemeral stream which covers an area of $245 \mathrm{~km}^{2}$ (Figure 1). It is located $35^{\circ} 26^{\prime}$ to $35^{\circ} 41^{\prime} \mathrm{E}$; and $30^{\circ} 00^{\prime}$ to $31^{\circ} 14^{\prime} \mathrm{N}$, and extends between

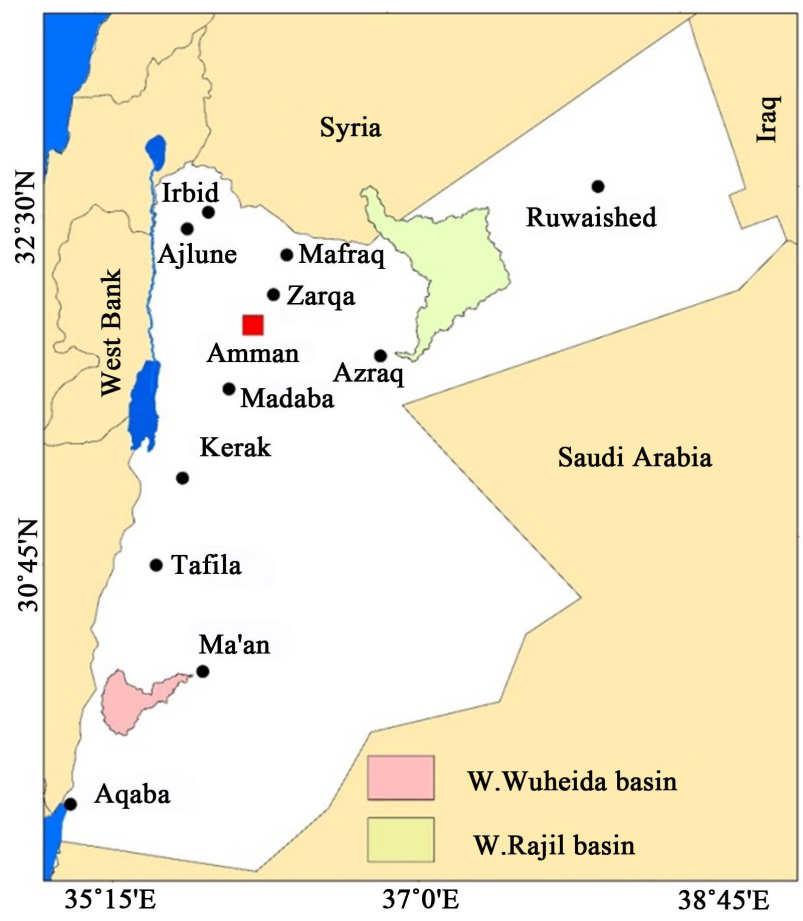

Figure 1 . The study watersheds. 
the crest line (rim), runs across Ra En Naqb escarpment and Sharah mountains in the west to the bridge of Ma'an on the Aqaba-Amman highway in the east, and discharges in El-Jafr depression. Wadi Wuheida and its tributaries drain part of Ras En Naqb escarpment (west of Ras En Naqb town), and part of Sharah mountains at a maximum average elevation of approximately $1719 \mathrm{~m}$ (a.s.l). The watershed rolls through steep to moderate and gentle-flat slopes across carbonate rocks of Upper Cretaceous age [36] towards El-Jafr depression in the east at an elevation of $1115 \mathrm{~m}$ (a.s.l) (Figure 2(a)). The watershed has a mushroom-like shape. The upper catchment is elongated north-south with an axis of $23 \mathrm{~km}$, where as the long axis of the wadi is about $27 \mathrm{~km}$ and extendsin a west-east direction. A prominent slope variation exists across the catchment $\left(0^{\circ}-5^{\circ}\right.$

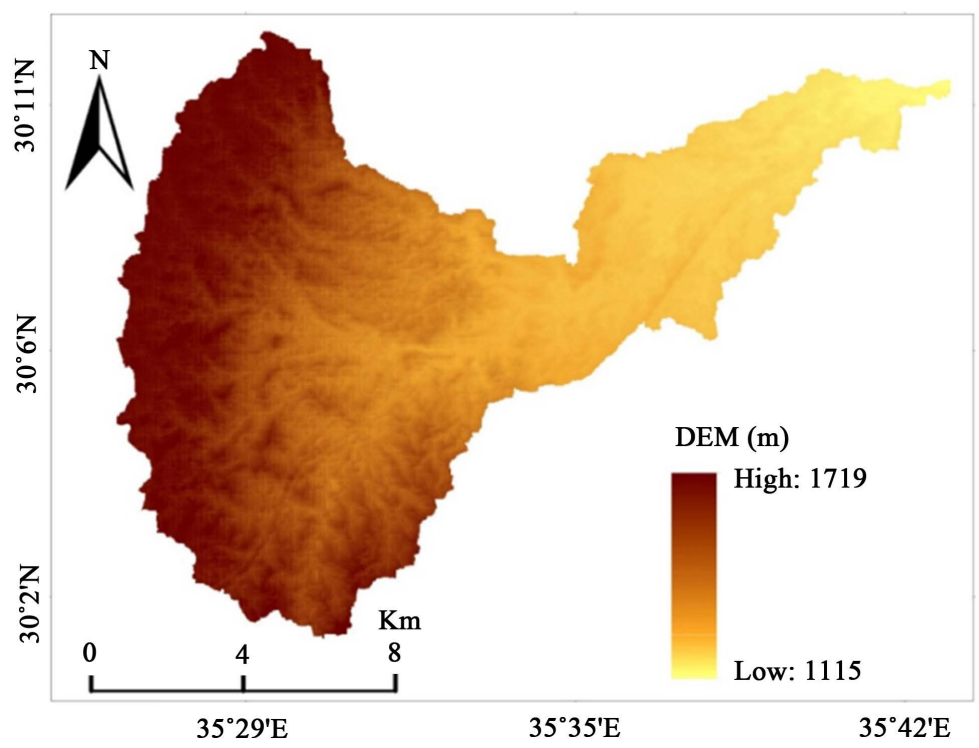

(a)

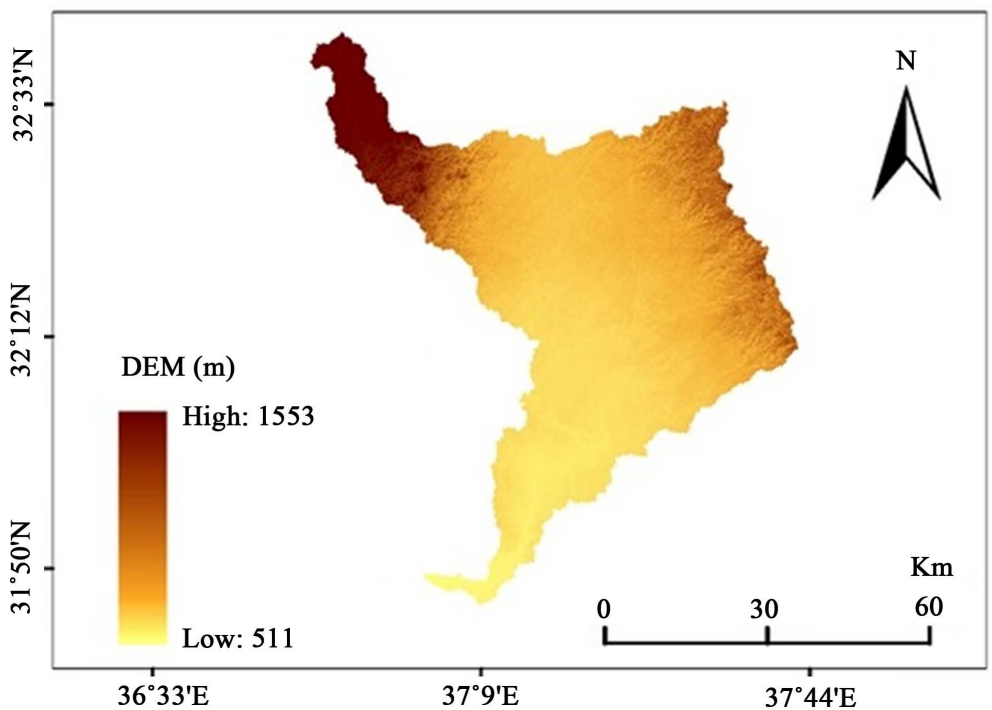

(b)

Figure 2. DEM of W. Wuheida (a) and DEM of W. Rajil (b). 
to $\left.>25^{\circ}\right)$. Higher slope categories dominated the upper reaches $\left(15^{\circ}-20^{\circ}, 20^{\circ}-\right.$ $25^{\circ}$, and $>25^{\circ}$ ). Whereas, slope categories of $0^{\circ}-5^{\circ}, 5^{\circ}-10^{\circ}$ and $10^{\circ}-15^{\circ}$ dominated the lower catchment (Figure 3(a)). The north-south elongation of the upper watershed locates it within the track of depressions which run either from west to east (frontal storms) or from southwest to northeast (Red Sea trough storms). The mushroom shape of the upper catchment comprises $56 \%$ of the total area of the watershed. Thus, it provides a larger headwater area, which consists of highlands of elevations $>1400 \mathrm{~m}$ and receives a higher annual rainfall approaching $160 \mathrm{~mm}$. In this regard, topographic characteristics of the watershed combined with the higher rainfall and slopes encourage high runoff potential. The catchment is classified as sixth order basin and of dendritic drainage pattern (Figure 4(a)). The Wuheida watershed-Ma'an-and El Jafr area is part of the Arabian Surface (the Oligocene peneplain) which has developed in the Eocene sediments [37].

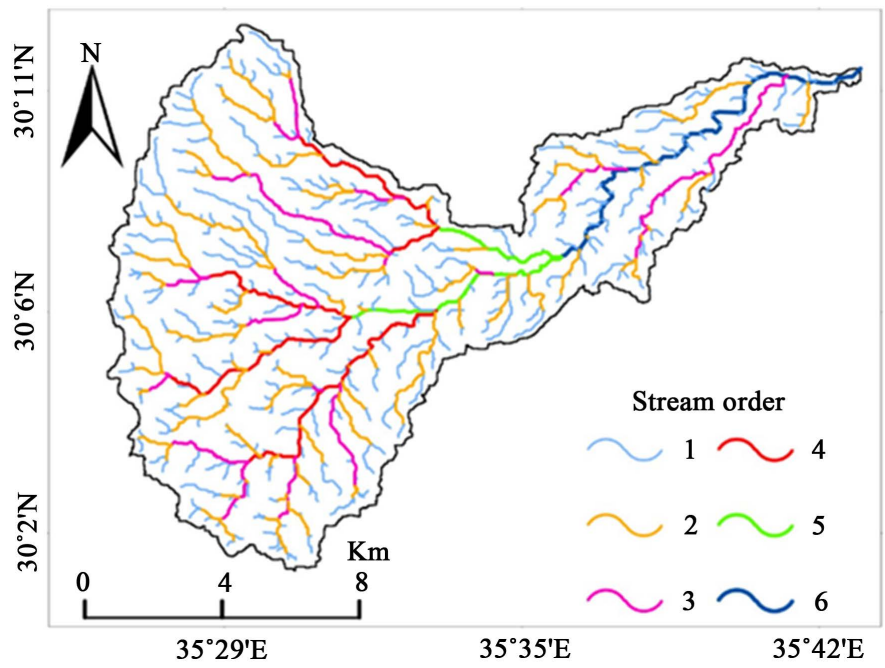

(a)

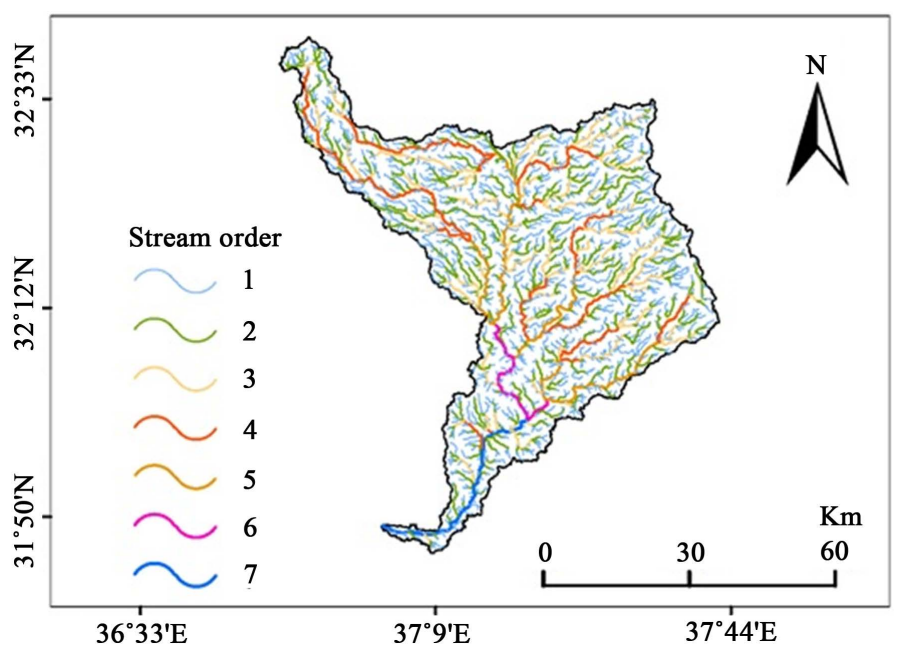

(b)

Figure 3. Drainage and stream order of W. Wuheida (a) and W. Rajil (b). 


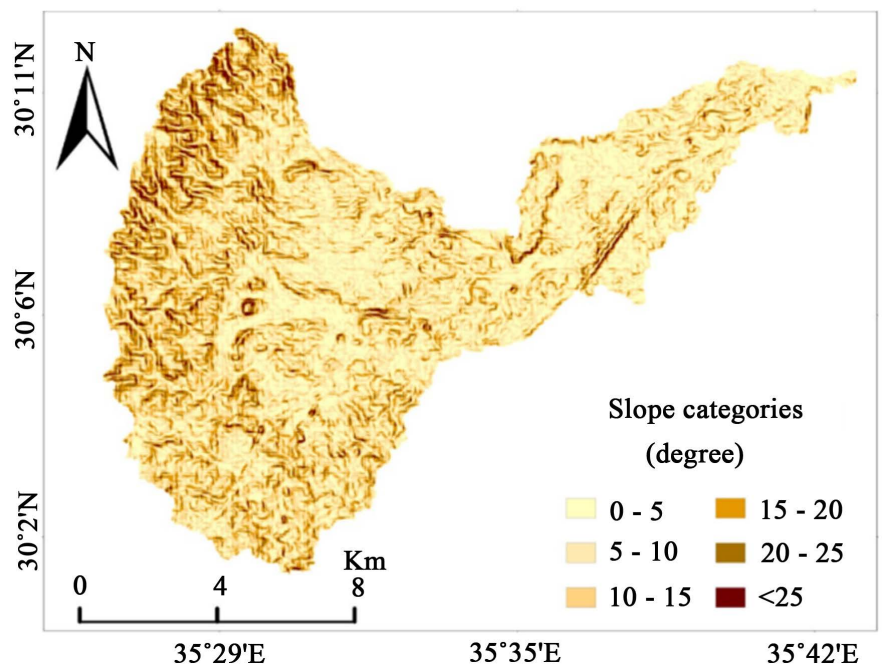

(a)

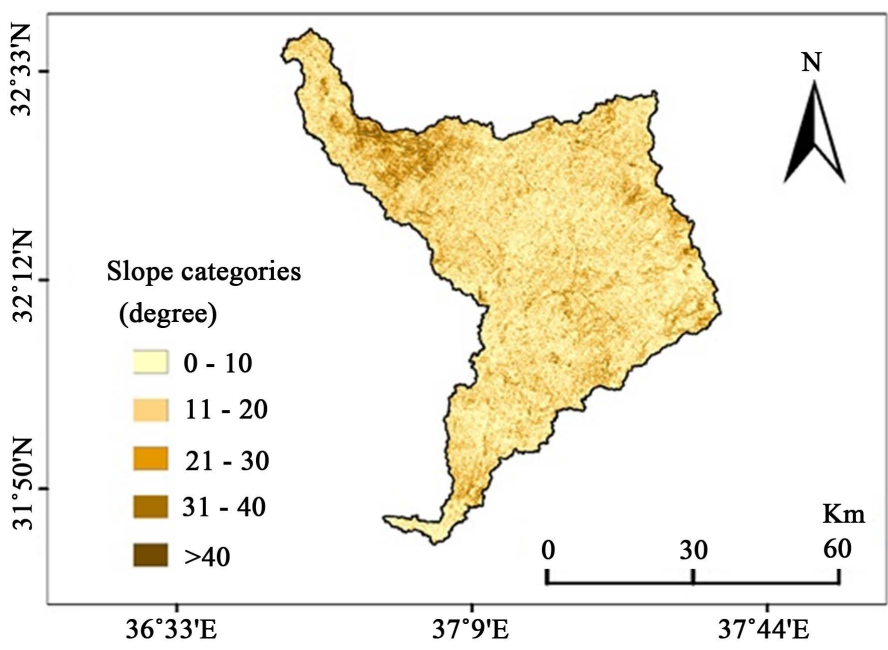

(b)

Figure 4. Slope categories of W. Wuheida (a) and W. Rajil (b).

Since early Miocene, and through Pliocene and Pleistocene, tectonic disturbances have affected the western and southwestern rims of these surfaces, thus giving rise to Ras En Naqb escarpment and Sharah mountains; uplifting of the eastern shoulder of the Rift; and basalt flows (Miocene to Pleistocene) to the south of El Jafr depression and the north eastern part of the Central Plateau including parts of Wadi Rajil catchment. Remnants of the Arabian Surface are still standing around Ma'an (including lower W. Wuheida), where a flat gentle stone Hamada surface formed and consists of wind-eroded chert residue, the flint-strewn "Hamada desert". The $\mathrm{B}^{2} / \mathrm{A}^{7}$ aquifer of Upper Cretaceous rocks constitutes the main aquifer in the catchment, and secure recharge at the headwater within the Asharah mountains and Ras En Naqb escarpment. Towards El-Jafr depression to the east, it becomes confined. The $\mathrm{B}^{2}$ (the Amman formation) consists of limestone with chert inter bedded with phosphatic layers and marls. Further, $\mathrm{A}^{7}$ (the Wadi Sir formation) is comprised of hard crystalline do- 
lomitic limestone, chalky limestone with chert bands and nodules. Um Rijamchert limestone formation $\left(\mathrm{B}^{4}\right)$ aquifer consists of limestone and chalky limestone [36] [38]. The $B^{4}$ aquifer receives limited water recharge during flash flooding [39]. The climate of Wadi Wuheida watershed is arid (BW). Rainfall amounts vary from $120-160 \mathrm{~mm}$ in the upper part, to $40 \mathrm{~mm}$ in Ma'an. Summer temperatures are hot and dry and winters are cold and relatively wet. Precipitation over the catchment is subjected to remarkable fluctuations. Relatively high precipitation in the upper catchment is affected by the orographic factor of Ras En Naqb and the Sharah Mts. Convective thunder storms which frequently occur in the fall (October-November) and spring (March-April) are influenced by the effect of the Red Sea trough and result in heavy rainfall events [40]. Several south-deepening Mediterranean depressions may affect southern Jordan from December to February. Snow may fall at high elevations (i.e., Ras En Naqb and Asharah highlands), and freezing temperatures were recorded in January and February. Average monthly temperatures range from $30^{\circ} \mathrm{C}$ (summer maximum) to about $7^{\circ}$ (winter minimum). Absolute average yearly maximum is approaching $43^{\circ} \mathrm{C}$, and absolute yearly minimum may reach- $8^{\circ} \mathrm{C}$ [41]. The low amount of rainfall results in poor vegetation cover, comprising of scattered acacia, tamarisk and cenapod, and some annual grasses. The land use/land cover is restricted to scattered and small patches of olive trees and woods in the highlands, and limited irrigated farming in El-Jafr and Ma'an.

Wadi Rajil watershed is located between $31^{\circ} 45^{\prime}$ and $32^{\circ} 36^{\prime} \mathrm{N}$ and $36^{\circ} 45^{\prime}$ and $37^{\circ} 43^{\prime} \mathrm{E}$ (Figure 1). The catchment has an area of $3085.87 \mathrm{~km}^{2}$ with $7.6 \%$ (236.469 $\mathrm{km}^{2}$ ) of the total surface located in Syrian territory. The wadi is considered one of the major wadis entering the Azraq depression from the north. Wadi Rajil takes a $\mathrm{NW}$-SE direction in the source area, then the direction changes from NE to SW, until it is terminated in the Azraq depression. The general shape of Wadi Rajil is trapezoidal, with its long axes generally oriented NE-SW direction. Terrain elevation ranges from $1553 \mathrm{~m}$ a.s.l at Salkhad in Syria, to 511 ma.s.l in Qa'a Azraq (Figure 2(b)). The entire Wadi Rajil watershed was found to be of seventh order (Figure 3(b)). Topographically, most of the catchment is nearly flat $\left(0^{\circ}-2^{\circ}\right)$, and undulating $\left(2^{\circ}-10^{\circ}\right)$ (Figure 4(b)). Wadi Rajil is part of the limestone plateau in east Jordan. $86.2 \%\left(2770.8 \mathrm{~km}^{2}\right)$ of the total catchment area is covered by six basalt flows, tuff, and volcanic eruption that originated mainly in Jebel el Druz in Syria from the early Miocene to historical time.

The youngest deposits exist in the watershed, the gravel and sand are of fluvial origin. These deposits cover $3.07 \%$ of the total catchment area, while the outcropping formations of Eocene age [42] are: the Rijam and Wadi Shallala formation in the central and eastern part of the catchment. It occupies $10.7 \%$ of the total catchment area. 16 fourth-order sub basins were demarcated in W. Rajil (Figure 5(b)).

Heavy thunder storms occur in April and May, causing major floods and inundation in the lower catchment and Qa'a Azraq. Flooded water remains in the 


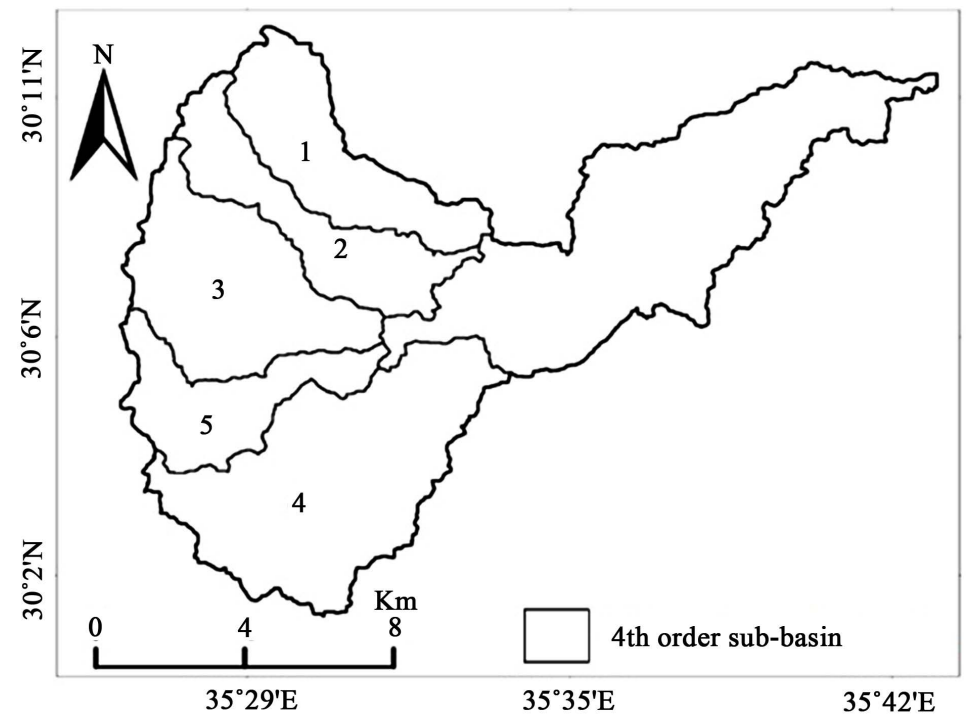

(a)

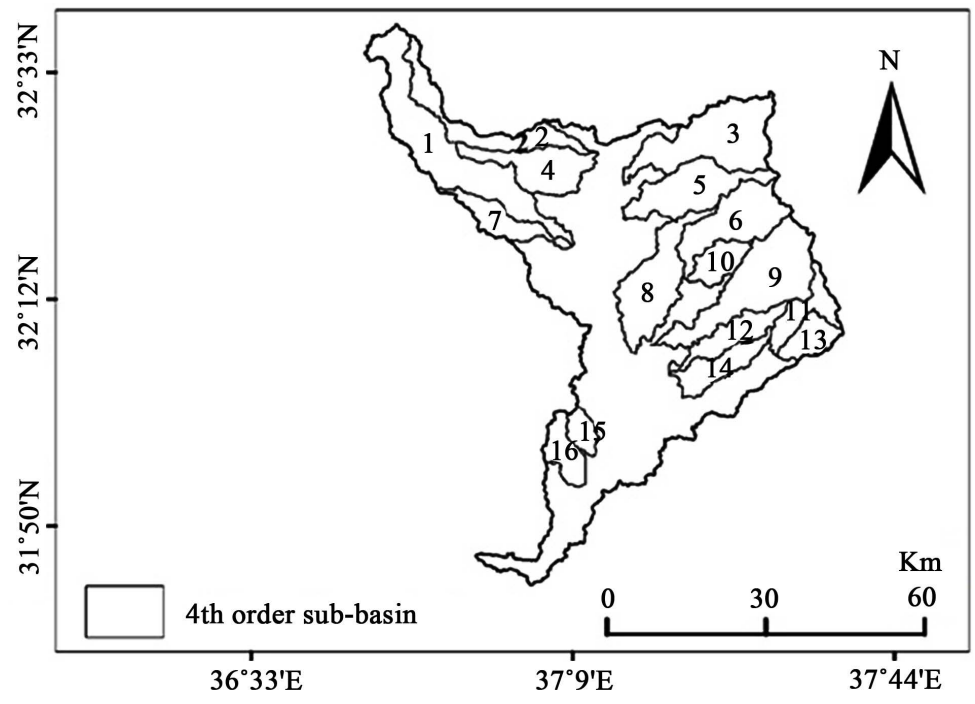

(b)

Figure 5. Fourth-order sub-bsins for W. Wuheida (a) and W. Rajil (b).

Qa'a for a few months before evaporation. The surface water potential of Wadi Rajil can be utilized for groundwater artificial recharge, where the calculated flood volumes are: $0.95,16.5,36.9$, and $61.5 \mathrm{MCM}$ for 10, 25, 50, and 100 year return periods [43]. Such large amounts of water encourage surface water harvesting and groundwater recharge, thus, protecting Azraq town and the irrigated farms from flooding. Deep long trenches refilled with available basalt boulders and gravel have been suggested for artificial recharge in Wadi Rajil and for other comparable watersheds in the northern Badia of Jordan. Annual rainfall ranges between $50 \mathrm{~mm}$ (Azraq town) to $300 \mathrm{~mm}$ close to Salkhad in Syria. The average annual rainfall over Wadi Rajil is about $127 \mathrm{~mm}$. Due to aridity, large seasonal and diurnal variation in temperature exist from a maximum $45^{\circ} \mathrm{C}$ in August to $-6^{\circ} \mathrm{C}$ in January. 


\section{Materials and Methods}

\subsection{Data Source and Methods}

Quantitative morphometric analysis of Wadi Rajil and Wadi Wuheida watersheds was performed using toposheets (1:50,000, and $20 \mathrm{~m}$ contour interval), ASTER DEM and Arc GIS (10.1) software packages. ASTER DEM is provided on line cost free to all researchers, and is available in Geo TiFF format and of 30 $\mathrm{m}$ spatial resolution. Recent investigation conducted on the Dead Sea (Jordan) to test the validity of ASTER DEM was compared with SRTM (the Shuttle Radar Topographic Mission) DEM, and referenced DEM constructed from a 1:25,000 scale topographic map [44]. It was concluded that the overall accuracy of the ASTER DEM is in line with the reported official accuracy specification [45]. The prepared topographic sheets were scanned, georeferenced, and converted to WGS1984, zone $36 \mathrm{~N}$ projection system using Arc GIS and the associated packages.

The two watersheds and the boundaries of the 21 fourth-order sub-basins were delineated initially using the topographic sheets. The ASTER DEM (v.2) was employed to demarcate watersheds and sub-basins boundaries, drainage networks using Arc Hydro tool (Figure 5). A total of 23 morphometric parameters were extracted and calculated using ASTER DEM, Arc GIS software, and the mathematical equations displayed in Table 1 . The results of computation are illustrated in Tables 2-4. Different topographic features such as aspect, slope, and elevation were generated using the Spatial Analyst module. Basic parameters include: basin area $(A)$ basin order $\left(N_{u}\right)$, perimeter $(P)$, basin length $\left(L_{b}\right)$, number of streams $\left(N_{u}\right)$, stream length $\left(L_{u}\right)$, mean stream length $\left(L_{s m}\right)$, length of main channel $\left(L_{m}\right)$. Derived parameters are: bifurcation ratio $\left(R_{b}\right)$, weighted mean bifurcation ratio $\left(\mathrm{WMR}_{\mathrm{b}}\right)$, stream length ratio $\left(R_{L}\right)$, sinuosity $(S I)$, basin shapeindex $\left(I_{s h}\right)$, length of overland flow $\left(L_{o}\right)$, RHO coefficient $(\rho)$, stream frequency $\left(F_{s}\right)$, drainage density $\left(D_{d}\right)$, drainage texture $\left(D_{t}\right)$, basin relief $\left(B_{h}\right)$, slope index $\left(S_{I n} \%\right)$, relief ratio $\left(R_{r}\right)$, ruggedness number $\left(R_{n}\right)$. Whereas shape parameters are: elongation ratio $\left(R_{e}\right)$, circularity ratio $\left(R_{c}\right)$, and form factor ratio $\left(R_{f}\right)$. The stream ordering for the entire Wadi Rajil and Wadi Wuheida was executed according to [24]. Thus, Wadi Rajil catchment was found to be of seventh-order, while Wadi Wuheida is found of sixth-order. Interpretation of parameter values was carried out according to the methods elaborated by [20], Strahler [21] [23] [24], Miller [46], and Schumm [25]. Efficient tools of GIS are capable of generating flood hazard, flood susceptibility, and sediment hazard maps, which illustrate flood-prone sub-basins. Risk and vulnerability maps help planners to assess the potential impact of floods [5], and to delimit the appropriate sites for future development; and to avoid sites exposed to flooding and sediment discharge. Based on the analysis of drainage, GIS afford devices which help not only to determine areas affected by floods, but to predict sites that are likely to be flooded in the future. Consequently, appropriate measures can be provided by planners to minimize the negative impact of floods and flooding effects. 
Table 1. Computation of basic, derived, and shape morphometric parameters.

\begin{tabular}{|c|c|c|c|}
\hline & Morphometric Parameters & Formula/Definition & References \\
\hline I & Basic Parameters & & \\
\hline 1 & Basin Area $(A)\left(\mathrm{Km}^{2}\right)$ & GIS Software Analysis & Schumm (1956) \\
\hline 2 & Basin Perimeter $(P)(\mathrm{Km})$ & GIS Software Analysis & Schumm (1956) \\
\hline 3 & Basin Length $\left(L_{b}\right)$ & GIS Software Analysis & Schumm (1956) \\
\hline 4 & No. of streams $\left(N_{u}\right)$ & Hierarchical Rank & Strahler (1952) \\
\hline 5 & Stream Length $\left(L_{u}\right)(\mathrm{Km})$ & $L_{u}=L_{1}+L_{2}+\cdots+L_{n}$ & Strahler (1964) \\
\hline 6 & Mean Stream Length $\left(L_{s m}\right)(\mathrm{Km})$ & $L_{s m}=L_{u} / N_{u} \quad(\mathrm{~km})$ & Horton (1945) \\
\hline II & Derived Parameters & & \\
\hline 7 & Bifurcation ratio $\left(R_{b}\right)$ & $R_{b}=N_{u} / N_{u+1}$ & Strahler (1964) \\
\hline 8 & Weighted mean bifurcation ratio $\left(W M R_{b}\right)$ & $W M R_{b}=\sum\left\{\left(R_{b} u / u+1\right) \times\left(N_{u}+N_{u}+1\right)\right\} / \sum N$ & Strahler (1953) \\
\hline 9 & Stream Length ratio $\left(R_{L}\right)$ & $R_{L}=L_{u} / L_{u-1}$ & Strahler (1964) \\
\hline 10 & Sinuosity $\left(S_{I}\right)$ & $S_{I}=L_{m} / L_{b}$ & Gregory and Walling (1973) [69] \\
\hline 11 & Basin shape index $\left(I_{s h} \%\right)$ & $I_{s h} \%=1.27 * A / L_{b}^{2}$ & Haggett (1965) [70] \\
\hline 12 & Length of overland flow $\left(L_{o}\right)$ & $L_{o}=1 / 2 D_{d}$ & Horton (1945) \\
\hline 13 & RHO coefficient $(\rho)$ & $\rho=R_{L} / R_{b}$ & Horton (1945) \\
\hline 14 & Stream frequency $\left(F_{s}\right)$ & $F_{s}=N_{u} / A$ & Horton (1932) \\
\hline 15 & Drainage density $\left(D_{d}\right) \mathrm{Km} / \mathrm{Km}^{2}$ & $D_{d}=L_{u} / A$ & Horton (1932) \\
\hline 16 & Drainage texture $\left(D_{t}\right)$ & $D_{t}=N_{u} / P$ & Horton (1945) \\
\hline 17 & Basin relief $\left(B_{h}\right) \mathrm{m}$ & $B_{h}=H-h$ & Strahler (1952) \\
\hline 18 & Slope index $\left(S_{I n} \%\right)$ & $\begin{array}{l}\qquad S_{I n} \%=\left(\mathrm{E} / 0.75 L_{m}\right) \times 100 \\
(E=\mathrm{E} 85-\mathrm{E} 10), \mathrm{E} 85 \text { and } \mathrm{E} 10 \text { are the } \\
\text { elevation of points at } 85 \% \text { and } 10 \% \text { of } \\
\text { the main channel from its mouth }) . \\
\left(L_{m}=\text { The length of main channel }\right. \\
\text { from its mouth to water divide }) .\end{array}$ & Majure and Soenksen (1991) [71] \\
\hline 19 & Relief ratio $\left(R_{r}\right)$ & $R_{r}=H / L_{b}$ & Schumm (1956) \\
\hline 20 & Ruggedness number $\left(R_{n}\right)$ & $R_{n}=\mathrm{D} \times\left(B_{h} / 1000\right)$ & Melton (1957) \\
\hline III & Shape Parameters & & \\
\hline 21 & Elongation ratio $\left(R_{e}\right)$ & $R_{e}=1.128 \sqrt{A / L_{b}}$ & Schumm (1956) \\
\hline 22 & Circularity ratio $\left(R_{c}\right)$ & $R_{c}=4 \pi A / P^{2}$ & Miller (1953) \\
\hline 23 & Form factor ratio $\left(R_{f}\right)$ & $R_{f}=A / L_{b}^{2}$ & Horton (1932) \\
\hline
\end{tabular}


Table 2. Morphometric characteristics of W. Wuheida.

\begin{tabular}{|c|c|c|c|c|c|c|c|c|}
\hline \multirow{2}{*}{ Par. no. } & \multirow{2}{*}{ Morphometric Parameters } & & \multicolumn{6}{|c|}{ Stream Order } \\
\hline & & & I & II & III & IV & $\mathrm{V}$ & VI \\
\hline I & Basic Parameters & & & & & & & \\
\hline 1 & Basin Area $(A)\left(\mathrm{Km}^{2}\right)$ & 244.97 & & & & & & \\
\hline 2 & Basin Perimeter $(P)(\mathrm{Km})$ & 135.33 & & & & & & \\
\hline 3 & Basin Length $\left(L_{b}\right)$ & 30.06 & & & & & & \\
\hline 4 & No. of streams $\left(N_{u}\right)$ & 490 & 387 & 76 & 19 & 5 & 2 & 1 \\
\hline 5 & Stream Length $\left(L_{u}\right)(\mathrm{Km})$ & 386.69 & 218.62 & 115.01 & 53.06 & 35.23 & 14.22 & 17.41 \\
\hline 6 & Mean Stream Length $\left(L_{s m}\right)(\mathrm{Km})$ & 2.98 & 0.56 & 1.51 & 2.79 & 7.05 & 7.11 & 17.41 \\
\hline \multirow[t]{2}{*}{ II } & Derived Parameters & & & & & & & \\
\hline & & & & II/I & III/II & IV/III & $\mathrm{V} / \mathrm{IV}$ & $\mathrm{VI} / \mathrm{V}$ \\
\hline 7 & Bifurcation ratio $\left(R_{b}\right)$ & & & 5.09 & 4 & 3.8 & 2.5 & 2 \\
\hline \multirow[t]{2}{*}{8} & Weighted mean bifurcation ratio $\left(W M R_{b}\right)$ & 3.8 & & & & & & \\
\hline & & & & II/I & $\mathrm{III} / \mathrm{II}$ & IV/III & V/IV & $\mathrm{VI} / \mathrm{V}$ \\
\hline 9 & Stream Length ratio $\left(R_{L}\right)$ & 0.55 & & 0.53 & 0.46 & 0.66 & 0.40 & 1.22 \\
\hline 10 & Sinuosity $\left(S_{I}\right)$ & 0.58 & & & & & & \\
\hline 11 & Basin shape index $\left(I_{s h}\right)$ & 0.34 & & & & & & \\
\hline 12 & Length of overland flow $\left(L_{o}\right)$ & 0.79 & & & & & & \\
\hline 13 & RHO coefficient $(\rho)$ & 0.16 & & & & & & \\
\hline 14 & Stream frequency $\left(F_{s}\right)$ & 2.00 & & & & & & \\
\hline 15 & Drainage density $\left(D_{d}\right) \mathrm{Km} / \mathrm{Km}^{2}$ & 1.58 & & & & & & \\
\hline 16 & Drainage texture $\left(D_{t}\right)$ & 3.62 & & & & & & \\
\hline 17 & Basin relief $\left(B_{h}\right) \mathrm{m}$ & 604 & & & & & & \\
\hline 18 & Slope index $\left(S_{I n} \%\right)$ & 0.08 & & & & & & \\
\hline 19 & Relief ratio $\left(R_{r}\right)$ & 20.10 & & & & & & \\
\hline 20 & Ruggedness number $\left(R_{n}\right)$ & 0.95 & & & & & & \\
\hline III & Shape Parameters & & & & & & & \\
\hline 21 & Elongation ratio $\left(R_{e}\right)$ & 0.59 & & & & & & \\
\hline 22 & Circularity ratio $\left(R_{c}\right)$ & 0.17 & & & & & & \\
\hline 23 & Form factor ratio $\left(R_{f}\right)$ & 0.27 & & & & & & \\
\hline
\end{tabular}

Table 3. Morphometric characteristics of W. Rajil.

\begin{tabular}{|c|c|c|c|c|c|c|c|c|c|}
\hline \multirow{2}{*}{$\begin{array}{c}\text { Par. } \\
\text { no. }\end{array}$} & \multirow{2}{*}{ Morphometric Parameter } & & \multicolumn{7}{|c|}{ Stream Order } \\
\hline & & & I & II & III & IV & $\mathrm{V}$ & VI & VII \\
\hline I & Basic Parameter & & & & & & & & \\
\hline 1 & Basin Area $(A)\left(\mathrm{Km}^{2}\right)$ & 3085.87 & & & & & & & \\
\hline 2 & Basin Perimeter $(P)(\mathrm{Km})$ & 608.61 & & & & & & & \\
\hline 3 & Basin Length $\left(L_{b}\right)$ & 126.73 & & & & & & & \\
\hline 4 & No. of streams $\left(N_{u}\right)$ & 1994 & 1563 & 331 & 75 & 17 & 6 & 2 & 1 \\
\hline 5 & Stream Length $\left(L_{u}\right)(\mathrm{Km})$ & 3004.4 & 1697.6 & 869.74 & 437.06 & 254.59 & 136.78 & 31.86 & 45.37 \\
\hline 6 & Mean Stream Length $\left(L_{s m}\right)(\mathrm{Km})$ & 6.13 & 1.09 & 2.63 & 5.83 & 14.98 & 22.80 & 15.93 & 45.37 \\
\hline \multirow[t]{2}{*}{ II } & Derived Parameters & & & & & & & & \\
\hline & & & & II/I & $\mathrm{III} / \mathrm{II}$ & IV/III & V/IV & $\mathrm{VI} / \mathrm{V}$ & V/VII \\
\hline 7 & Bifurcation ratio $\left(R_{b}\right)$ & & & 4.72 & 4.4 & 4.4 & 2.8 & 3 & 2 \\
\hline
\end{tabular}




\section{Continued}

\begin{tabular}{|c|c|c|c|c|c|c|c|c|}
\hline \multirow[t]{2}{*}{8} & \multirow[t]{2}{*}{ Weighted mean bifurcation ratio $\left(W M R_{b}\right)$} & \multirow[t]{2}{*}{3.88} & & & & & & \\
\hline & & & $\mathrm{II} / \mathrm{I}$ & III/II & IV/III & $\mathrm{V} / \mathrm{IV}$ & $\mathrm{VI} / \mathrm{V}$ & V/VII \\
\hline 9 & Stream Length ratio $(R L)$ & 0.53 & 0.51 & 0.50 & 0.58 & 0.54 & 0.23 & 1.42 \\
\hline 10 & Sinuosity $\left(S_{I}\right)$ & 0.25 & & & & & & \\
\hline 11 & Basin shape index $\left(I_{s h}\right)$ & 0.24 & & & & & & \\
\hline 12 & Length of overland flow $\left(L_{o}\right)$ & 0.49 & & & & & & \\
\hline 13 & RHO coefficient $(\rho)$ & 0.14 & & & & & & \\
\hline 14 & Stream frequency $\left(F_{s}\right)$ & 0.65 & & & & & & \\
\hline 15 & Drainage density $\left(D_{d}\right) \mathrm{Km} / \mathrm{Km}^{2}$ & 0.97 & & & & & & \\
\hline 16 & Drainage texture $\left(D_{t}\right)$ & 3.28 & & & & & & \\
\hline 17 & Basin relief $\left(B_{h}\right) \mathrm{m}$ & 604 & & & & & & \\
\hline 18 & Slope index $\left(S_{I n} \%\right)$ & 0.02 & & & & & & \\
\hline 19 & Relief ratio $\left(R_{r}\right)$ & 4.77 & & & & & & \\
\hline 20 & Ruggedness number $\left(R_{n}\right)$ & 0.59 & & & & & & \\
\hline III & Shape Parameters & & & & & & & \\
\hline 21 & Elongation ratio $\left(R_{e}\right)$ & 0.49 & & & & & & \\
\hline 22 & Circularity ratio $\left(R_{c}\right)$ & 0.10 & & & & & & \\
\hline 23 & Form factor ratio $\left(R_{f}\right)$ & 0.19 & & & & & & \\
\hline
\end{tabular}

Table 4. Morphometric characteristics of the 21 sub-watersheds.

\begin{tabular}{|c|c|c|c|c|c|c|c|c|c|c|c|c|c|c|c|c|c|c|c|c|c|c|}
\hline \multirow{2}{*}{ Basin } & \multirow{2}{*}{$\begin{array}{l}\text { Sub- } \\
\text { basin }\end{array}$} & \multicolumn{21}{|c|}{ Morphometric parameter } \\
\hline & & $A$ & $P$ & $L_{b}$ & $N_{u}$ & $L_{u}$ & $L_{s m}$ & $R_{b}$ & $W M R_{b}$ & $R_{L}$ & $S_{I}$ & $I S H$ & $L_{o}$ & $\rho$ & $F_{s}$ & $D_{d}$ & $D_{t}$ & $B_{h}$ & $S_{I n} \%$ & $R_{r}$ & $R_{n}$ & $R_{c} \quad R_{f}$ \\
\hline \multirow{16}{*}{ 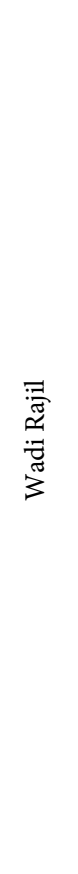 } & 1 & 280.33 & 203.37 & 32.45 & 179 & 331.61 & 17.91 & 5.47 & 4.65 & 1.00 & 0.22 & 0.34 & 0.59 & 0.18 & 0.64 & 1.18 & 0.88 & 843 & 1.26 & 25.98 & 1.00 & $\begin{array}{lll}0.58 & 0.09 & 0.27\end{array}$ \\
\hline & 2 & 119.12 & 148.41 & 19.96 & 71 & 134.11 & 11.71 & 4.24 & 4.55 & 1.45 & 0.35 & 0.38 & 0.56 & 0.34 & 0.60 & 1.13 & 0.48 & 790 & 1.05 & 39.59 & 0.89 & $\begin{array}{lll}0.62 & 0.07 & 0.30\end{array}$ \\
\hline & 3 & 210.83 & 133.01 & 27.60 & 144 & 225.30 & 9.04 & 4.88 & 4.48 & 0.69 & 0.26 & 0.35 & 0.53 & 0.14 & 0.68 & 1.08 & 1.08 & 290 & 0.20 & 10.51 & 0.31 & $\begin{array}{lll}0.59 & 0.150 .28\end{array}$ \\
\hline & 4 & 116.91 & 93.19 & 19.74 & 63 & 134.20 & 6.59 & 4.06 & 5.35 & 0.57 & 0.36 & 0.38 & 0.57 & 0.14 & 0.54 & 1.15 & 0.68 & 498 & 0.04 & 25.22 & 0.57 & $\begin{array}{lll}0.62 & 0.17 & 0.30\end{array}$ \\
\hline & 5 & 142.64 & 108.90 & 22.11 & 95 & 163.41 & 5.73 & 4.92 & 4.99 & 0.49 & 0.32 & 0.37 & 0.57 & 0.10 & 0.67 & 1.15 & 0.87 & 320 & 0.04 & 14.48 & 0.37 & $\begin{array}{lll}0.61 & 0.15 & 0.29\end{array}$ \\
\hline & 6 & 145.92 & 103.18 & 22.39 & 78 & 170.44 & 7.64 & 3.96 & 4.34 & 0.64 & 0.32 & 0.37 & 0.58 & 0.16 & 0.53 & 1.17 & 0.76 & 333 & 0.19 & 14.87 & 0.39 & $\begin{array}{lll}0.61 & 0.17 & 0.29\end{array}$ \\
\hline & 7 & 70.30 & 90.23 & 14.79 & 41 & 90.56 & 4.86 & 3.44 & 4.75 & 0.60 & 0.48 & 0.41 & 0.64 & 0.17 & 0.58 & 1.29 & 0.45 & 434 & 0.11 & 29.34 & 0.56 & 0.640 .110 .32 \\
\hline & 8 & 161.06 & 123.50 & 23.69 & 105 & 186.90 & 6.51 & 4.34 & 4.17 & 0.59 & 0.30 & 0.36 & 0.58 & 0.14 & 0.65 & 1.16 & 0.85 & 204 & 0.06 & 8.61 & 0.24 & $\begin{array}{lll}0.60 & 0.13 & 0.29\end{array}$ \\
\hline & 9 & 226.85 & 139.58 & 28.77 & 130 & 252.71 & 9.11 & 4.70 & 4.79 & 0.58 & 0.25 & 0.35 & 0.56 & 0.12 & 0.57 & 1.11 & 0.93 & 376 & 0.22 & 13.07 & 0.42 & $\begin{array}{lll}0.59 & 0.150 .27\end{array}$ \\
\hline & 10 & 53.57 & 52.93 & 12.67 & 39 & 61.76 & 2.65 & 3.21 & 3.89 & 0.47 & 0.56 & 0.42 & 0.58 & 0.15 & 0.73 & 1.15 & 0.74 & 148 & 0.01 & 11.68 & 0.17 & $\begin{array}{lll}0.65 & 0.24 & 0.33\end{array}$ \\
\hline & 11 & 73.51 & 90.73 & 15.17 & 48 & 66.05 & 4.39 & 3.39 & 4.14 & 1.42 & 0.47 & 0.41 & 0.45 & 0.42 & 0.65 & 0.90 & 0.53 & 248 & 0.23 & 16.35 & 0.22 & 0.640 .110 .32 \\
\hline & 12 & 65.70 & 81.77 & 14.23 & 50 & 79.93 & 6.26 & 3.57 & 3.87 & 0.84 & 0.50 & 0.41 & 0.61 & 0.24 & 0.76 & 1.22 & 0.61 & 261 & 0.16 & 18.34 & 0.32 & $\begin{array}{lll}0.64 & 0.12 & 0.32\end{array}$ \\
\hline & 13 & 53.47 & 49.15 & 12.66 & 46 & 60.72 & 1.36 & 4.21 & 3.59 & 0.50 & 0.56 & 0.42 & 0.57 & 0.12 & 0.86 & 1.14 & 0.94 & 185 & 0.01 & 14.61 & 0.21 & $\begin{array}{lll}0.65 & 0.28 & 0.33\end{array}$ \\
\hline & 14 & 71.55 & 78.13 & 14.94 & 50 & 79.35 & 3.65 & 3.74 & 5.18 & 0.52 & 0.47 & 0.41 & 0.55 & 0.14 & 0.70 & 1.11 & 0.64 & 187 & 0.03 & 12.52 & 0.21 & 0.640 .150 .32 \\
\hline & 15 & 31.20 & 35.11 & 9.32 & 19 & 55.34 & 3.62 & 2.61 & 3.30 & 0.60 & 0.76 & 0.46 & 0.89 & 0.23 & 0.61 & 1.77 & 0.54 & 89 & 0.01 & 9.55 & 0.16 & $\begin{array}{lll}0.68 & 0.32 & 0.36\end{array}$ \\
\hline & 16 & 55.52 & 52.73 & 12.93 & 45 & 66.23 & 3.69 & 3.40 & 4.25 & 1.37 & 0.55 & 0.42 & 0.60 & 0.40 & 0.81 & 1.19 & 0.85 & 91 & 0.04 & 7.04 & 0.11 & $\begin{array}{lll}0.65 & 0.25 & 0.33\end{array}$ \\
\hline \multirow{5}{*}{ 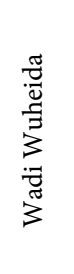 } & 1 & 27.50 & 38.40 & 8.68 & 53 & 49.89 & 2.78 & 3.48 & 4.09 & 0.74 & 0.82 & 0.46 & 0.91 & 0.21 & 1.93 & 1.81 & 1.38 & 413 & 0.20 & 47.59 & 0.75 & $\begin{array}{llll}0.68 & 0.23 & 0.37\end{array}$ \\
\hline & 2 & 24.98 & 45.32 & 8.22 & 42 & 44.28 & 2.34 & 3.50 & 4.89 & 0.52 & 0.26 & 0.47 & 0.89 & 0.15 & 1.68 & 1.77 & 0.93 & 385 & 0.18 & 46.85 & 0.68 & $\begin{array}{lll}0.69 & 0.15 & 0.37\end{array}$ \\
\hline & 3 & 38.03 & 40.44 & 10.43 & 66 & 70.23 & 2.69 & 3.87 & 5.23 & 0.58 & 0.60 & 0.44 & 0.92 & 0.15 & 1.74 & 1.85 & 1.63 & 346 & 0.27 & 33.16 & 0.64 & 0.670 .290 .35 \\
\hline & 4 & 21.43 & 39.06 & 7.53 & 42 & 43.64 & 4.43 & 3.50 & 4.89 & 3.94 & 1.95 & 0.48 & 1.02 & 1.12 & 1.96 & 2.04 & 1.08 & 319 & 0.14 & 42.35 & 0.65 & $\begin{array}{lll}0.69 & 0.18 & 0.38\end{array}$ \\
\hline & 5 & 59.22 & 54.72 & 13.42 & 135 & 108.37 & 3.99 & 4.74 & 4.62 & 0.61 & 0.85 & 0.42 & 0.92 & 0.13 & 2.28 & 1.83 & 2.47 & 336 & 0.15 & 25.04 & 0.61 & $\begin{array}{lll}0.65 & 0.25 & 0.33\end{array}$ \\
\hline
\end{tabular}




\subsection{Flash Flood Analysis Methods}

Quantitative analysis of drainage basin morphometry using remote sensing and GIS techniques has been employed recently to assess the probability of flash flood hazard. Various methods were employed in this regard. The most common is the morphometric assessment method which comprises:

1) El-Shamy's approach [27]

2) The morphometric ranking method [47]

3) Wahid's flash flood rating method [48] and the

4) Morphometric hazard degree assessment method [28] [29] [30]

5) Morphometric analysis of drainage basin and curve number (CN) method to evaluate flash flood hazard [3] [49].

In the present research, two different morphometric analysis methods have been adopted to evaluate the hazard degree of flash floods, and to generate flooding susceptibility maps. These methods are: El-Shamy's approach for assessing flooding hazard probability [5] [27]. The second method is the "morphometric hazard degree assessment" [28] [29] [30] [50]. The second method is a semi-quantitative measure which determined flash flood hazard based on eleven morphometric parameters.

El-Shamy [27] employed three morphometric parameters to assess the hazard potential of flash floods for different sub-basins. These are: drainage density $\left(D_{d}\right)$, stream frequency $\left(F_{s}\right)$, and bifurcation ratio $\left(R_{b}\right)$. He elaborated two different morphometric relationships to determine the flood hazard degree for a catchment or sub-basin; bifurcation ratio $\left(R_{b}\right)$ versus drainage density $\left(D_{d}\right)$, and bifurcation ratio versus stream frequency $\left(F_{s}\right)$. The empirical diagram established by El-Shamy [27] was divided into three zones. The first zone $(A)$ is characterized by high susceptibility for flash flooding and low possibility for groundwater recharge. The second zone $(B)$ is characterized by moderate susceptibility for flash floods, and moderate possibility for groundwater recharge. The third zone $(C)$ is characterized by low susceptibility for flash floods and high possibility for groundwater recharge. The data from the diagram represent bifurcation ratio $\left(R_{b}\right)$ vs. stream frequency $\left(F_{s}\right)$, and the diagram illustrates that bifurcation ratio $\left(R_{b}\right)$ vs. drainage density $\left(D_{d}\right)$ are used to determine the overall hazard degree. If a sub-basin is plotted in zone B of the first diagram (moderate susceptibility of flash floods), and located in zone $\mathrm{C}$ of the second diagram (low susceptibility for flash floods), the overall hazard degree for this sub-basin will be low possibility for flash floods which represents the more "conservative" situation [5].

The morphometric hazard degree assessment method employed eleven morphometric parameters with a direct effect on flash floods [30]. Eight parameters are characterized with a direct proportional relationship with the degree of risk, whereas three parameters have an inverse proportional relationship with the degree of risk (Table 5). A hazard scale number was designed, starting with (1) representing the lowest hazard up to (5) indicating the highest hazard, and has 
Table 5. Effective morphometric parameters based on the kind of relationship with the degree of risk.

\begin{tabular}{ll}
\hline \multicolumn{2}{c}{ Relationship with hazard } \\
\hline Direct proportional relationship & \multicolumn{1}{c}{ Inverse proportional relationship } \\
\hline 1) Area $(A)$ & \\
2) Drainage density $\left(D_{d}\right)$ & 1) Mean bifurcation ratio $\left(R_{b}\right)$ \\
3) Stream frequency $\left(F_{s}\right)$ & 2) Length overland flow $\left(L_{o}\right)$ \\
4) Basin shape index $\left(S_{f}\right)$ & 3) Sinuosity $\left(S_{I}\right)$ \\
5) Relief ratio $\left(R_{I}\right)$ & \\
6) Ruggedness number $\left(R_{n}\right)$ & \\
7) Slope index $\left(S_{I n} \%\right)$ & \\
8) Drainage texture ratio $\left(T_{t}\right)$ &
\end{tabular}

been assigned to all parameters. The distributions of the hazard degrees for the sub-basins of Wadi Rajil and Wadi Wuheida have been calculated in order to:

1) Determine the minimum and maximum values for each morphometric parameter for all sub-basins of Wadi Rajil and Wadi Wuheida,

2) Assess the actual hazard degree for all the parameters which are located between the minimum and maximum values, depending on a test to extract the empirical relation between the relative hazard degree of a sub-basin with respect to flash floods and the morphometric parameters, and

3) The equal spacing or simple linear interpolation between data points procedure was chosen [51].

For parameters which show a direct proportional relationship to the degree of risk, the hazard degree was calculated using the following equation [28] [29]:

$$
\text { Hazard degree }=\frac{4\left(X-X_{\min }\right)}{X_{\max }-X_{\min }}+1
$$

Likewise, for parameters which show an inverse proportional relationship to degree of risk, the hazard degree is calculated using the following equation:

$$
\text { Hazard degree }=\frac{4\left(X-X_{\max }\right)}{X_{\min }-X_{\max }}+1
$$

where $X$ is the value of the morphometric parameters to be assessed for the hazard degree for each sub-basin, $X_{\min }$ and $X_{\max }$ are the minimum and maximum values of the morphometric parameters of the two basins and all sub-basins respectively. The summation of the hazard degree $(1+2)$ for each sub-basin represents the final flood hazard of these sub-basins.

An integration of the results was carried out using the morphometric hazard degree assessment method, and El-Shamy's model. Such a procedure was performed through superimposition of flood risk maps generated through the application of the two estimation methods. The product enables us to recognize the common sub-basins falling under each category of flooding risk; and to identify the most risk-prone sub-basins with reference to flash flooding. It also, allows the possibility to demarcate the most vulnerable sub-basins against flooding. 


\section{Morphometric Analysis of Watersheds}

Quantitative analysis was conducted for W. Rajil and W. Wuheida catchments and the 21 fourth-order sub-catchments connected to both watersheds, in order to evaluate the morphometric properties of the drainage networks, based on twenty-five morphometric descriptors classified as: basic, derived, and shape parameters. These variables are utilized to characterize the two arid watersheds, and to improve our understanding of arid watershed development in relation to essential controlling factors, i.e., geology (lithology and structure), tectonic and geomorphic processes, and rejuvenation. The results of morphometric analysis for the two watersheds (Table 2 and Table 3 ) and the 21 sub-basins are illustrated in Table 4. The drainage pattern is dendritic to sub-dendritic and sub-trellis in the southern part of W. Wuheida, whereas, it is trellis to sub-trellis in the southwestern and northeastern parts of W. Rajil, then changing to sub-dendritic in the northwestern part of the watershed. Referring to the ratio between basin area $(A)$, and perimeter $(P)$, the ratio is found 5.071:1 for W. Rajil, and 1.810:1 for W. Wuheida. Such figures indicate that the borderline of W. Rajil is a highly irregular water divide compared to W. Wuheida which is a slightly irregular water divide. The noticeable difference in the ratios between $(A)$ and $(\mathrm{P})$, has been verified by a striking differences in stream frequency $\left(F_{s}\right)$ and drainage density $\left(D_{d}\right)$ values. Although the number of streams and the area $(A)$ of W. Wuheida are smaller compared to W. Rajil, the drainage network of W. Wuheida is more developed and integrated. Conversely, $86.2 \%$ of Wadi Rajil is covered by six basalt flows ranging in age from Oligocene to Pleistocene [52]; thus, the drainage network of W. Rajil was impeded from becoming integrated due to the progression of volcanic eruptions.

\subsection{Basic Morphometric Parameters}

The basic morphometric parameters computed for W. Rajil and W. Wuheida and the 21 sub-basins comprising basin area $(A)$, basin perimeter $(P)$, basin length $\left(L_{b}\right)$, stream length $\left(L_{u}\right)$, mean stream length $\left(L_{s m}\right)$, and length of main channel $\left(L_{m}\right)$.

\subsubsection{Basin Area $(A)$, Basin Length $\left(L_{b}\right)$, and Basin Perimeter $(P)$}

The area of a drainage basin is an essential morphometric parameter for hydrological data processing, analysis and interpretation. Larger basins and sub-basins with high local relief generally have greater discharge, thus directly influencing runoff and peaks magnitude. For this reason, basin area is an important component in hydrological processes [53]. In this regard, Chorley et al. [54] argued that the maximum discharge of flood per unit area is inversely related to the area of the drainage basin. The total drainage area for W. Rajil is $3085.87 \mathrm{~km}^{2}$, and for W. Wuheida is $245 \mathrm{~km}^{2}$; for the 21 sub-basins, it varies from 21.4 to $280.33 \mathrm{~km}^{2}$. The basin length represents the maximum length of the watershed and sub-watersheds measured parallel to the main drainage line. The length of Wadi Rajil basin is $126.73 \mathrm{~km}$ and Wadi Wuheida $30 \mathrm{~km}$, while the lengths of the 
sub-basins range from 7.53 to $28.77 \mathrm{~km}$. The perimeter of W. Rajil is $608.61 \mathrm{~km}$, and $\mathrm{W}$. Wuheida is $135.33 \mathrm{~km}$. The perimeters of the sub-basins vary from 35.11 to $203.37 \mathrm{~km}$ (Table 4). Sub-watershed no.15 of W. Rajil, represents the shortest one, whereas, sub-basinno.10 of the same watershed has the longest perimeter. Equally, sub-watershed no.1 is the longest, but with the highest perimeter. With reference to the area, sub-basin no. 1 of W. Rajil is the largest, and sub-basin no. 4 of W. Wuheida is the smallest.

\subsubsection{Stream Order $(u)$ and Stream Number $\left(N_{u}\right)$}

Stream ordering has been assigned based on the number and type of tributary junction. The two watersheds and the sub-basins were ranked according to the stream ordering system developed by Strahler [24]. Stream order represents a preparatory indicator of stream size, drainage area and discharge. The total number of streams in W. Rajil watershed is 1995, and the first order streams account for $78.3 \%$ of the total stream numbers. The total number of streams in W. Wuheida is 490 , and the first order streams constitute $79 \%$ of the total streams. The details of stream characteristics validate Horton's [20] first law, or, the "law of stream number," which stated that the number of steams of different order in a given drainage basin tends to closely approximate an inverse geometric ratio [55]. W. Rajil consists of 16 sub-basins which are assigned as fourth-order basins, and W. Wuheida is composed of 5 sub-basins of the same order. Application of Strahler's ordering procedure through Arc GIS (10.1) reveals that W. Rajil is classified as seventh order; and W. Wuheida is sixth order.

\subsubsection{Stream Length $\left(L_{u}\right)$ and Mean Stream Length $\left(L_{s m}\right)$}

Stream length is calculated from the mouth of stream to drainage divide. $L_{u}$ is a dimensional parameter utilized to understand the characteristics of the drainage network elements and its contributing basin surfaces [24]. $L_{u}$ is an important variable employed to examine the hydrological characteristics of the drainage basin, i.e., surface runoff and the hydrological properties of the underlying bedrock such as permeability. Streams of short length generally are characteristic of terrain with greater slopes and highly dissected with very fine textures. Longer stream lengths are often developed where the bedrocks are permeable. Details of stream length characteristics of W. Rajil and W. Wuheida support Horton's [20] "law of stream length" which states that "the average length of streams of each of the different orders in a drainage basin tends closely to approximate a direct geometric ratio". Variation in order and size of the tributary basins are largely attributed to morphological (relief and slope), structural, tectonic and geomorphic evolution of the drainage basin. The total stream length is generally high in the first order streams and decreases as the stream order increases. The total stream length of W. Rajil is $3004.4 \mathrm{~km}$, and for W. Wuheida is $386.7 \mathrm{~km}$, and the first order streams account for $56.5 \%$ of the total stream length of both watersheds. Mean stream length is calculated by dividing the total stream length of order $(u)$ and number of stream segments of the same order $(u)$. The mean 
stream length for W. Rajil varies from $1.09 \mathrm{~km}$ for the first order streams to $45.37 \mathrm{~km}$ for the seventh-order stream (Table 3), whereas the mean stream length for $\mathrm{W}$. Wuheida ranges from $0.56 \mathrm{~km}$ for the first order streams to 17.41 $\mathrm{km}$ for the sixth-order stream (Table 2). The $L_{s m}$ value for any given order is greater than that of the lower order and less than that of its next higher order. For the 21 sub-basins, the $L_{s m}$ values vary from 0.56 for the first-order streams, to 22.8 for the fourth-order streams.

\subsection{Derived Morphometric Parameters}

\subsubsection{Bifurcation Ratio $\left(R_{b}\right)$ and Weighted Mean Bifurcation Ratio $\left(\mathrm{WMR}_{\mathrm{b}}\right)$}

The bifurcation ratio $\left(R_{b}\right)$ refers to the ratio of the number of streams of a given order $\left(N_{u}\right)$ to the number of streams in the next higher orde $\left(N_{u}+1\right)$. Horton [20] elaborated $R_{b}$ parameter as a morphological index of relief and dissection. For flat or rolling catchments, the $R_{b}$ value is $\approx 2$, while the value for dissected catchments approaches 4 . To achieve a more illustrative bifurcation value, Strahler [56] employed a weighted mean bifurcation ratio $\left(W M R_{b}\right)$ calculated according to the following equation:

$$
W M R_{b}=\sum\left\{\left(R_{b} u / u+1\right) \times\left(N_{u}+N_{u}+1\right)\right\} / \sum N
$$

Later, Shumm [25] adopted this method to determine the mean bifurcation ratio $\left(R_{b}\right)$ of a drainage basin at Perth Amboy, New Jersey, where the value is found to be 4.87. $R_{b}$ values vary from 2 to 4.72 , and the weighted mean bifurcation ratio $\left(W M R_{b}\right)$ is 4.6 for $\mathrm{W}$. Rajil (Table 3 ). Likewise, the $R_{b}$ values range from 2 to 5, and the $W M R_{b}$ value is 3.8 for W. Wuheida (Table 3 and Table 4). Higher values of $R_{b}$ and $W M R_{b}$ for W. Rajil indicate that the wadi is largely affected by progressive tectonic activity during the eruption of successive basalt flows. Whereas W. Wuheida experienced less structural distortions, and mainly affects the water divide area at Ras En Naqb. The trend of $R_{b}$ values in W. Rajil from the second-order stream to seventh-order stream is relatively irregular due to the tectonic activity mentioned above. By contrast, the trend of $R_{b}$ values in W. Wuheida decreases regularly from the second-order streams to the sixth-order stream due to the presence of homogeneous surface rock strata in Ras En Naqb in the south, and El-Jafr depression in the north.

\subsubsection{Stream Length Ratio $\left(R_{L}\right)$ and Sinuosity $\left(S_{I}\right)$}

Stream length ratio $\left(R_{L}\right)$ refers to the ratio between the individual lengths of steam in a given order and the total length of streams in the next order [20]. $R_{L}$ parameter reveals a significant relationship with surface flow discharge and the erosional stage and geomorphic development of the drainage basin [53] [57]. As a result of morphological variation (i.e., slope and relief) over a watershed, $R_{L}$ values vary considerably. The $R_{L}$ value for W. Rajil is 0.3 , and for W. Wuheida is 0.55 , whereas $R_{L}$ values for the 21 sub-basins vary from 0.51 for the first-order streams to 0.66 for the fourth-order streams. Sinuosity $\left(S_{I}\right)$ is defined as the ratio 
of the maximum length of the main channel $\left(L_{m}\right)$ to basin length $\left(L_{b}\right)$ or,

$$
S_{I}=L_{m} / L_{b}
$$

Generally, $S_{I}$ values range from 1 to 4 . Streams having $S_{I}$ value of 1.5 are described as sinuous. When $S_{I}$ values exceed 1.5, streams are described as meandering [58]. Sinuosity $\left(S_{I}\right)$ is considered a significant morphometric parameter which helps in interpreting the geomorphic evolution of a watershed.

\subsubsection{Basin Shape Index $\left(I_{s h}\right)$ and Slope Index $\left(S_{I n} \%\right)$}

The basin slope index $\left(I_{s h}\right)$ describes the relation between the basin area, and the length of the drainage basin. W. Rajil and W. Wuheida attain basin shape index values of 0.24 and 0.34 respectively. These values reveal an elongated drainage basin; thus a reasonable chance is available for groundwater recharge. Slope index $\left(S_{I n} \%\right)$, or the slope of main channel of a given basin is considered to be of hydrological significance [59]. Steep channels occasionally have high surface runoff values, and low infiltration rates, which in turn accelerate soil erosion. Therefore, sediment load production tends to be high in arid watersheds, where slopes are overgrazed and barren [11] [60]. Slope index $\left(S_{I I} \%\right)$ is also an indicator for the channel slope from which an assessment of the runoff volume can be estimated [30]. The two arid watersheds under consideration are characterized by medium to high relief, where the slope index $\left(S_{I n} \%\right)$ values are 0.02 for W. Rajil, and 0.08 for W. Wuheida.

\subsubsection{Length of Overland Flow $\left(L_{o}\right)$ and RHO Coefficient $(\rho)$}

RHO coefficient $(\rho)$ is defined as the ratio between the length ratio $\left(R_{L}\right)$ and the bifurcation ratio $\left(R_{b}\right)$ [20]. $\rho$ parameter is influenced by physical (geological, geomorphic, climatic and biologic) and anthropogenic factors [61]. The relationship between drainage density $\left(D_{d}\right)$ and the geomorphic evolution of a drainage basin is determined by the RHO parameter. Consequently it helps to assess the storage capacity of the drainage network [20]. A high RHO value of a watershed is indicative of a high hydric storage during flooding; therefore, the erosion effect is decreased during the raised discharge [59]. The RHO values for W. Rajil and W. Wuheida are 0.14 and 0.16 respectively (Table 2 and Table 3 ). Whereas RHO values for the 21 sub-basins range from 0.10 to 0.42 (Table 4). Length of overland flow $\left(L_{o}\right)$ is defined as the length of water over the ground before it gets concentrated into stream channels or permanent drainage channels [62]. The shorter the length of overland flow the quicker surface runoff will enter the stream. In the current study, the length of overland flow $\left(L_{o}\right)$ for W. Rajil is 0.49 and for W. Wuheida is 0.79 . Such values indicate that $L_{o}$ for W. Rajil is shorter than W. Wuheida, due to variation in slope, lithology, land cover, rainfall intensity and infiltration capacity [53]. The slope index value for W. Rajil is 0.02 which is noticeably less than the slope index value of $\mathrm{W}$. Wuheida (0.08). These values denote that surface water concentration in $\mathrm{W}$. Wuheida is faster compared with W. Rajil. The larger value of average $L_{o}$ is close to half the aver- 
age of the distance between the stream channels. Thus, it is equal to approximately half of the $D_{d}$ value [20]. The long-term evolution of a drainage basin and landforms development is also affected by $\mathrm{L}_{\mathrm{o}}$ parameter. The $L_{o}$ values for the 21 sub-basins vary from 0.45 to 1.02 (Table 4 ).

\subsubsection{Stream Frequency $\left(F_{s}\right)$, Drainage Density $\left(D_{d}\right)$, and Drainage Texture $\left(D_{t}\right)$}

Stream frequency $\left(F_{s}\right)$ refers to the ratio of the total number of streams $\left(N_{u}\right)$ of all orders in a basin and the basin area [20]. Stream frequency is affected by lithology and underlying materials; therefore, it is an expression of drainage texture of watersheds and sub-basins. The values of $F_{s}$ are positively correlated with $D_{d}$ values of the catchment. Consequently any increase in stream segments is associated with that of drainage density [63]. High $F_{s}$ values indicate low impermeability and low infiltration rate of surface water; thus, increased runoff is noted. Such hydrological conditions make the watersheds and the sub-watershed more prone to flooding, surface erosion, and landslide activity. The $F_{s}$ value for W. Rajil is relatively low (0.65), while $F_{s}$ value for W. Wuheida is moderate (2.0) which denotes that fractured and weathered basalt covered most of W Rajil compared with more solid carbonate rocks exposed across $\mathrm{W}$. Wuheida. The values of $F_{s}$ for the 21 sub-basins range from 0.53 to 2.28 . Drainage density $\left(D_{d}\right)$ is defined as the total length of stream per unit area divided by the area of the watershed [20]. $D_{d}$ value refers to the closeness of spacing of channels; therefore, it is a quantitative measure for relief dissection, runoff potential, and thus, in turn the drainage efficiency of watersheds. High $D_{d}$ values denote high runoff and low infiltration rate due to the presence of impermeable underlying materials, spare vegetation, and hilly relief. Conversely, low drainage density implies low runoff, high infiltration and groundwater recharge. The achieved value of $D_{d}$ for W. Rajil is $0.97 \mathrm{~km} / \mathrm{km}^{2}$ (Table 3), and for W. Wuheida 1.58 (Table 2). High $D_{d}$ value for W. Wuheida implies a high potential runoff from large headwater area over the Ras En Nagb highlands, and consequently high flooding potential down the wadi [17]. $D_{d}$ values for the 21 sub-basins range from 0.90 to 2.04 (Table 4). Drainage texture $\left(D_{t}\right)$ represents the total number of stream segments of all orders per unit perimeter of the basin [20]. Drainage texture is controlled by: lithology, soil, relief, vegetation, infiltration-capacity and climate. $\mathrm{D}_{\mathrm{t}}$ reflects the relative channel spacing within a drainage network. According to Smith [64], $D_{t}$ tends to be coarse $(2-4)$ in initial and early stages of the erosion cycle, and fine (6 - 8) in maturity stage. Barren soft rocks (i.e., Lisan marl or the "Kata" in the Jordan Rift) produce a fine $(6-8)$ and very fine $(>8)$ texture although it is developed under arid climate. Whereas massive limestone rocks in northern Jordan produce a coarse texture though landforms were developed under a dry-Mediterranean (semi-humid) climate. The $D_{t}$ value for W. Rajil is 3.28, and for $\mathrm{W}$. Wuheida 3.62. These values imply that the texture of both catchments is coarse, while the $D_{t}$ values for the 21 sub-basin range from 0.45 to 2.47. 


\subsubsection{Basin Relief $\left(B_{h}\right)$, Relief Ratio $\left(R_{r}\right)$ and Ruggedness Number $\left(R_{n}\right)$}

Basin relief $\left(B_{h}\right)$ or total relief is the elevation difference between the highest and lowest point in a given watershed [25]. $B_{h}$ parameter significantly controls flooding patterns and sediment production by controlling stream gradient. Basin relief is a measure of the potential energy of drainage basins. Thus, it is essential to understand the denudational status of a catchment, drainage network development, overland flow, through flow, and the fluvial-erosional conditions of a catchment. Increase in $B_{h}$ value caused high surface runoff, and low infiltration; thus increasing surface erosion and sediment production. The basin relief value of both W. Rajil and W. Wuheida is $604 \mathrm{~m}$, and for the 21 sub-basins it varies from $89 \mathrm{~m}$ to $843 \mathrm{~m}$. High soil erosion loss and sediment production, and high flooding potential is predictable for both watersheds. Schumm [25] elaborated relief ration $\left(R_{r}\right)$ as a dimensionless height-length ratio between the basin relief $\left(B_{h}\right)$ and basin length $\left(L_{b}\right)$. The $R_{r}$ variable allows comparison of the relative relief of any catchment regardless of the differences in scale of topography. $R_{r}$ values normally increase with decreasing catchment areas. For example in the W. Wala catchment, southern Jordan, the $R_{r}$ value is 15.1 , whereas $R_{r}$ values for 23 fourth-order sub-basins vary from 0.5 to 76.1 . The basin relief values range from $96 \mathrm{~m}$ to $459 \mathrm{~m}$ [65]. Small relief ratio reveals the dominance of gentle slopes $\left(3^{\circ}\right.$ $5^{\circ}$ ) and the subdued topography across the watershed. $R_{r}$ ratio and other relief morphometric parameters generally indicate the level of basin energy, erosion potential of processes operating over a catchment, and sediment transport efficiency [61]. The relief ratio for W. Rajil is 4.77, for W. Wuheida is 20.1, and for the 21 sub-basins it ranges from 7.04 to 47.59 . Ruggedness number $\left(R_{n}\right)$ is a dimensionless parameter representing the product of basin relief $\left(B_{h}\right)$ and the drainage density [21] [24]. The $R_{n}$ parameter has been elaborated to measure the flash flood potential of a drainage basin [66] and to illustrate the geometric characteristics of drainage basins [67]. High values of $R_{n}$ obtain when both relief and drainage density are large. Present analysis shows that $R_{n}$ for W. Rajil is 0.59 , and for W. Wuheida is 0.95 . Watersheds having high $R_{n}$ values $(>0.5)$ are highly susceptible to an increase in peak discharge, high soil erosion rates, and high sediment load production [55].

\subsection{Shape Morphometric Parameters}

\subsubsection{Elongation Ratio $\left(R_{e}\right)$}

Elongation ratio $\left(R_{e}\right)$ is defined as the ratio between the diameter of a circle having the same area as the basin $(A)$, and the basin length $\left(L_{b}\right)$ [25]. Strahler [24] reported that $R_{e}$ ratio vary from 0.6 and 1.0 for a wide range of geomorphic environment. Values close to 1.0 are characteristic of watersheds with low relief. Whereas values in the range $0.6-0.8$ are typical for catchments with high relief and steep slopes. Low values of $R_{e}(<0.5)$ imply that drainage basins are more elongated, and at the youth-age stage of geomorphic evolution. When $R_{e}$ values approach 1.0, the shape of the drainage basin approaches a circle [25]. A circular basin suggests an early mature-age stage of geomorphic evolution [53], and is 
more efficient in runoff discharge than is an elongated one [68]. The $R_{e}$ value of W. Rajil is 0.49 (Table 3), and for W. Wuheida is 0.59 (Table 2), which imply that these watersheds are more elongated, and elongated, respectively.

\subsubsection{Circularity Ratio $\left(R_{c}\right)$}

Circularity ratio $\left(R_{c}\right)$ parameter is indicative of basins shape, and the rate of infiltration including the time needed for excess water to reach the basin outlet. $R_{c}$ refers to the ratio of the basin area $(A)$ and the area of a circle with the same perimeter $(P)$ as the basin [24]. Low, medium, and high values of $R_{c}$ denote young, mature, and old stages of the geomorphic cycle of the catchment. Drainage basins of different circularity ratio, ranging from 0.4 to 0.5 , were considered by Miller [46] as strongly elongated, with homogeneous bedrock and regolith materials, and a uniform rate of infiltration. Consequently, the excess runoff takes a longer time to reach the basin outlet. More elongated or elongated shapes allow drainage basins to be slow in disposing water, which resulted in a broad and low-peaked hydrograph. Thus, reduction of water velocity can be attained through the construction of water harvesting structures, i.e., dams and surface reservoirs [30]. The $R_{c}$ value of W. Rajil is 0.10 , and for W. Wuheida is 0.17 , and for the 21 sub-basins, it ranges from 0.07 to 0.32 (Table 4 ).

\subsubsection{Form Factor Ratio $\left(R_{f}\right)$}

The form factor parameter has been elaborated by Horton [20] to forecast the flow intensity of a given watershed. It refers to the ratio between the area of ba$\sin (A)$ and the square of the basin length $\left(L_{b}\right) . R_{f}$ values vary from 0 for highly elongated shape, to 1 for a perfect circular shape of the basin. Catchments with low $R_{f}$ value, tend to be elongated, which implies low peak flows for longer duration, and thus of less probability for the basin to flood. Furthermore, catchments with high $R_{f}$ values experience high peak flow of short duration, where the floods will be stronger and have higher velocities associated with greater erosion and transport capacities. The $R_{f}$ value for W. Rajil is 0.19 (Table 3), and for W. Wuheida is 0.24 (Table 2). The $R_{f}$ values for the 21 sub-basins range from 0.24 to 0.38 . These values indicate that both watersheds and the related sub-basins are more elongated and elongated in shape with low peak flows of longer duration.

\section{Results and Discussion}

Two approaches were employed to assess flash floods hazards and flooding risk for two arid watersheds in Jordan. W. Rajil Watershed in the north which is developed over the basalt "Harra", and W. Wuheida in the south, developed in the "Hamada" landscape. The potential hazard was analyzed, and sub-basins vulnerable to flooding, and expected to cause heavy damages to the local inhabitants, their livelihood, and infrastructure, were demarcated. Past experience reveals that Ma'an city and the surroundings, the Amman-Aqaba highway, Azraq town and Qa'a Azraq were exposed to recurrent severe floods of different magnitudes as a result of favorable climatic conditions introduced by the Red Sea Trough (RST), or the frontal con- 
vective storms. In order to assess the hazardous effects of flash floods on the 16 forth-order sub-basins of W. Rajil, and five sub-basins related of W. Wuheida, fourteen hydro-morphometric parameters were utilized in the analysis. The two methods employed are: 1) El-Shamy's approach [27] for flooding hazard assessment (El-Shamy 1992) which is based on three morphometric parameters; and 2) The morphometric hazard degree assessment method [28] [29] [30]. The second method is considered a semi-quantitative measure determined on the bases of eleven morphometric parameters.

\subsection{Flash Flood Risk Assessment: El-Shamy's Approach}

Following El-Shamy's approach, the relationship between the Bifurcation ratio $\left(R_{b}\right)$ versus Drainage density $\left(D_{d}\right)$, and the bifurcation ratio versus Stream frequency $\left(F_{s}\right)$, morphometric data for the sub-basins of W. Rajil (termed 1 - 16) and W. Wuheida (desighnated 1 - 5) were plotted in line with El-Shamy's diagram (Figure 6(a) and Figure 6(b)). With reference to W. Rajil, the estimation

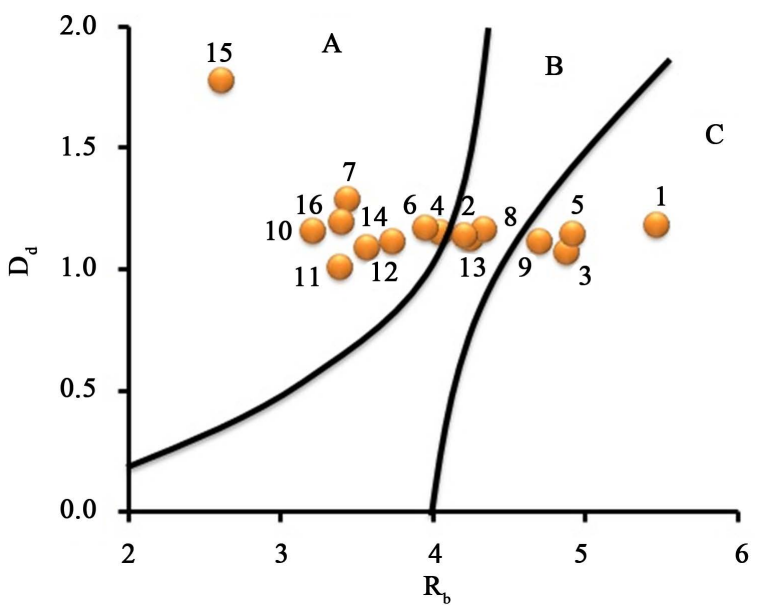

(a)

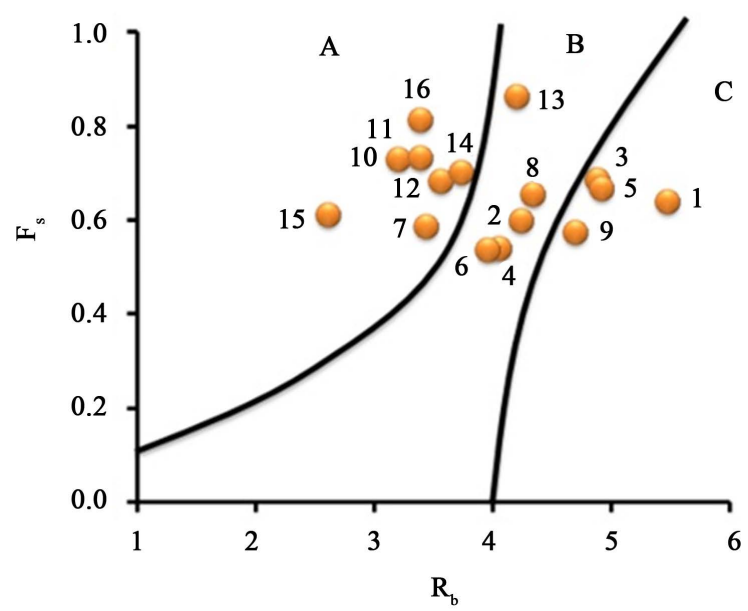

(b)

Figure 6. Flooding susceptibility of W. Rajil based on El-Shamy's approach, $R_{b}$ vs. $D_{d}$ (a) and $R_{b}$ vs. $F_{s}(\mathrm{~b})$. 
of flash flood risk based on the relation between $R_{b}$ and $D_{d}$ reveals that nine sub-basins $(4,6,7,10,11,12,14,15$, and 16) are located in Zone $(A)$ and represent high flooding susceptibility for flash floods. Three sub-basins $(2,8$, and 13) are located in zone (B), which represent moderate susceptibility for flash floods, and four sub-basins (1, 3, 5 and 9)are located in zone (C), which represent low susceptibility for flash floods (Figure 6(a) and Table 6(a)). Additionally, and based on the relation between Bifurcation ratio versus Stream frequency, seven sub-basins $(7,10,11,12,14,15$ and 16) are located in zone $(A)$, which represents high susceptibility for flash floods, and five sub-basins $(2,4,6$, 8 and 13) are located in zone (B), which represents moderate susceptibility for

Table 6. Hazard degree analysis for W. Rajil (a) ad W. Wuheida (b) (based on El-Shamy's approach 1992).

(a)

\begin{tabular}{ccccccc}
\hline Sub-basin no. & $R_{b}$ & $F_{s}$ & $\mathrm{HD} 1$ & $D_{d}$ & $\mathrm{HD} 2$ & $\mathrm{FHD}$ \\
\hline 1 & 5.47 & 0.64 & $\mathrm{~L}$ & 1.18 & $\mathrm{~L}$ & $\mathrm{~L}$ \\
2 & 4.24 & 0.60 & $\mathrm{M}$ & 1.13 & $\mathrm{M}$ & $\mathrm{H}$ \\
3 & 4.88 & 0.68 & $\mathrm{~L}$ & 1.07 & $\mathrm{~L}$ & $\mathrm{~L}$ \\
4 & 4.06 & 0.54 & $\mathrm{M}$ & 1.15 & $\mathrm{H}$ & $\mathrm{H}$ \\
5 & 4.92 & 0.67 & $\mathrm{~L}$ & 1.15 & $\mathrm{~L}$ & $\mathrm{~L}$ \\
6 & 3.96 & 0.53 & $\mathrm{M}$ & 1.17 & $\mathrm{H}$ & $\mathrm{H}$ \\
7 & 3.44 & 0.58 & $\mathrm{H}$ & 1.29 & $\mathrm{H}$ & $\mathrm{H}$ \\
8 & 4.34 & 0.65 & $\mathrm{M}$ & 1.16 & $\mathrm{M}$ & $\mathrm{M}$ \\
9 & 4.70 & 0.57 & $\mathrm{~L}$ & 1.11 & $\mathrm{~L}$ & $\mathrm{~L}$ \\
10 & 3.21 & 0.73 & $\mathrm{H}$ & 1.15 & $\mathrm{H}$ & $\mathrm{H}$ \\
11 & 3.39 & 0.73 & $\mathrm{H}$ & 1.01 & $\mathrm{H}$ & $\mathrm{H}$ \\
12 & 3.57 & 0.68 & $\mathrm{H}$ & 1.09 & $\mathrm{H}$ & $\mathrm{H}$ \\
13 & 4.21 & 0.86 & $\mathrm{M}$ & 1.14 & $\mathrm{M}$ & $\mathrm{M}$ \\
14 & 3.74 & 0.70 & $\mathrm{H}$ & 1.11 & $\mathrm{H}$ & $\mathrm{H}$ \\
15 & 2.61 & 0.61 & $\mathrm{H}$ & 1.77 & $\mathrm{H}$ & $\mathrm{H}$ \\
16 & 3.40 & 0.81 & $\mathrm{H}$ & 1.19 & $\mathrm{H}$ & $\mathrm{H}$ \\
\hline 15 & & & & & &
\end{tabular}

(b)

\begin{tabular}{ccccccc}
\hline Sub-basin no. & $R_{b}$ & $F_{s}$ & $\mathrm{HD} 1$ & $D_{d}$ & $\mathrm{HD} 2$ & $\mathrm{FHD}$ \\
\hline 1 & 3.48 & 1.93 & $\mathrm{H}$ & 1.81 & $\mathrm{H}$ & $\mathrm{H}$ \\
2 & 3.50 & 1.68 & $\mathrm{H}$ & 1.77 & $\mathrm{H}$ & $\mathrm{H}$ \\
3 & 3.87 & 1.74 & $\mathrm{M}$ & 1.85 & $\mathrm{M}$ & $\mathrm{M}$ \\
4 & 3.50 & 1.96 & $\mathrm{H}$ & 2.04 & $\mathrm{H}$ & $\mathrm{H}$ \\
5 & 4.74 & 2.28 & $\mathrm{M}$ & 1.83 & $\mathrm{M}$ & $\mathrm{M}$ \\
\hline
\end{tabular}

$R_{b}=$ Bifurcation Ratio, $\mathrm{F}_{\mathrm{s}}=$ Stream Frequency, $D_{d}=$ Drainage Density, HD1 = Hazard degree $R_{b}$ vs. $F_{s}$, HD2 $=$ Hazard degree $R_{b}$ vs. $D_{d}$ and FHD = Final hazard degree from HD1 and HD2. L: low susceptibility for flash floods; M: moderate susceptibility for flash floods; and H: high susceptibility for flash floods. 
flash floods. Finally, four sub-basins (1, 3, 5, and 9) are located in zone (C) which represents low susceptibility foe flash floods (Figure 6(b)). Through integration of the results achieved based on the relation between $R_{b}$ vs. $D_{d}$ and $R_{b}$ vs. $F_{s}$, showed that sub-basins $1,3,5$, and 9 are categorized under low possibility of flash floods in both relations (Figure 7). While sub-basins 2, 8, and 13 are grouped under moderate possibility of flash floods. Likewise, sub-basins 7, 10, $11,12,14,15$ and 16 are classified under high susceptibility for flash floods based on both relations, except for sub-basins 6 and 4 .

With respect to W. Wuheida and based on the relation between Bifurcation ratio $\left(R_{b}\right)$ vs. Drainage density $\left(D_{d}\right)$, it is found that two sub-basins (3 and 5) are located in zone $(B)$ which represents moderate susceptibility for flash floods, and three sub-basins (1, 2, and 4) are located in zone (A) which represents high possibility for flash floods (Figure 8(a), Table 6(b)). None of the sub-basins were categorized in zone $(C)$ of low flooding susceptibility for flash floods. Based on the relation between Bifurcation ratio vs. stream frequency, three sub-basins (2, 3 and 5$)$ are located in zone $(B)$ which represents moderate susceptibility for flash floods, and sub-basins ( 1 and 4 ) are located in zone $(A)$ which represents high susceptibility for flash floods (Figure 8(b), Table 6(b)). Again through integration of the results based on the relation between $R_{b}$ vs. $D_{d}$ and $R_{b}$ vs. $F_{s}$ sub-basins 3 and 5 are grouped under the category of moderate susceptibility for flash floods, based on both relations (Figure 9). In parallel, sub-basins 1, 2 and 4 are ranked under the category of high susceptibility for flash floods. None of the sub-basins are ranked in the category of low susceptibility for flash floods (Figure 9) It is evident that similar and consistent results were achieved regarding

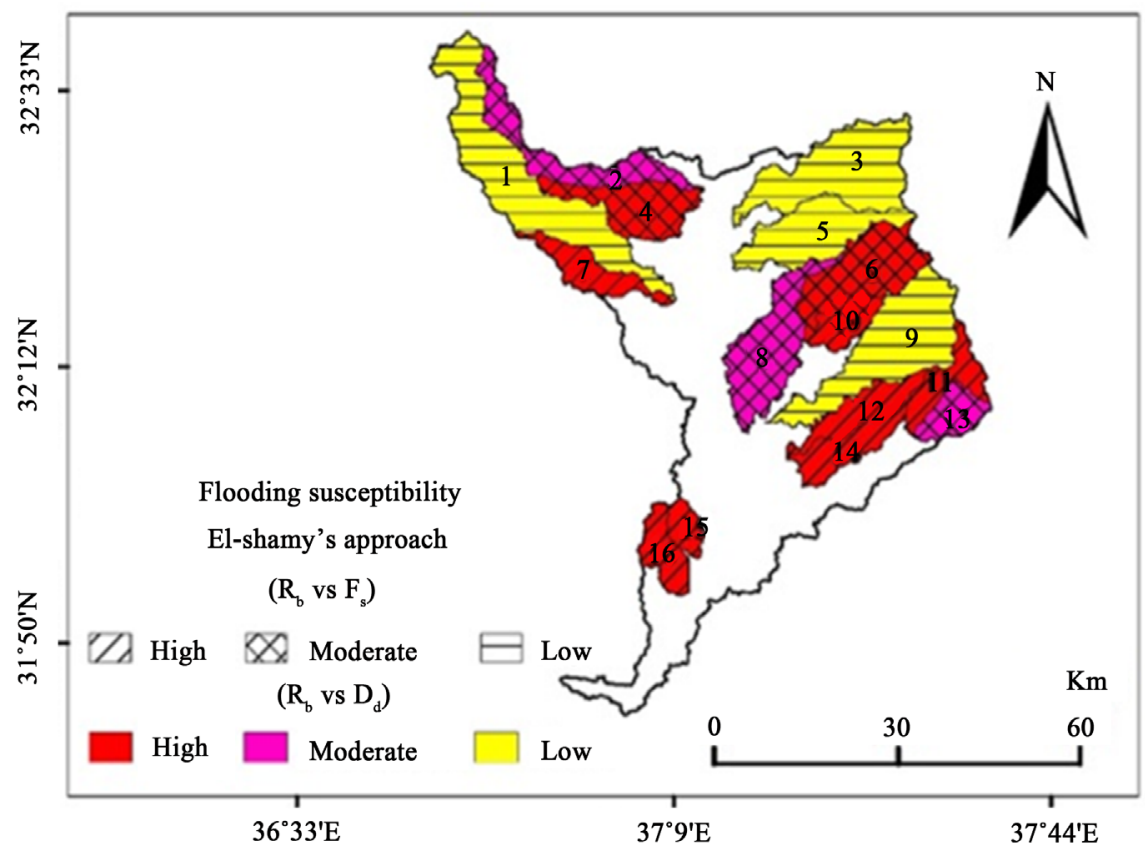

Figure 7. Flooding susceptibility of W. Rajil based on El-Shamy's approach $\left(R_{b}\right.$ vs. $D_{d}$ layer superimposed on $R_{b}$ vs. $F_{s}$ layer). 


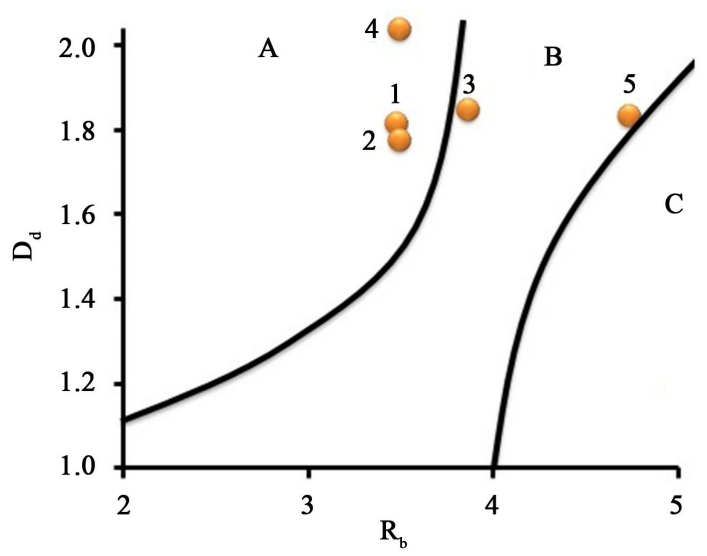

(a)

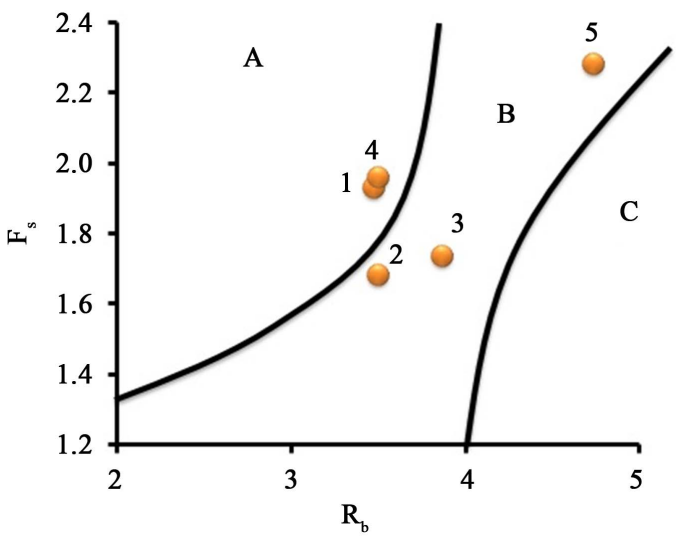

(b)

Figure 8. Flooding susceptibility of W. Wuheida based on El-Shamy's approach, $R_{b}$ vs. $D_{d}$ (a) and $R_{b}$ vs. $F_{s}(\mathrm{~b})$.

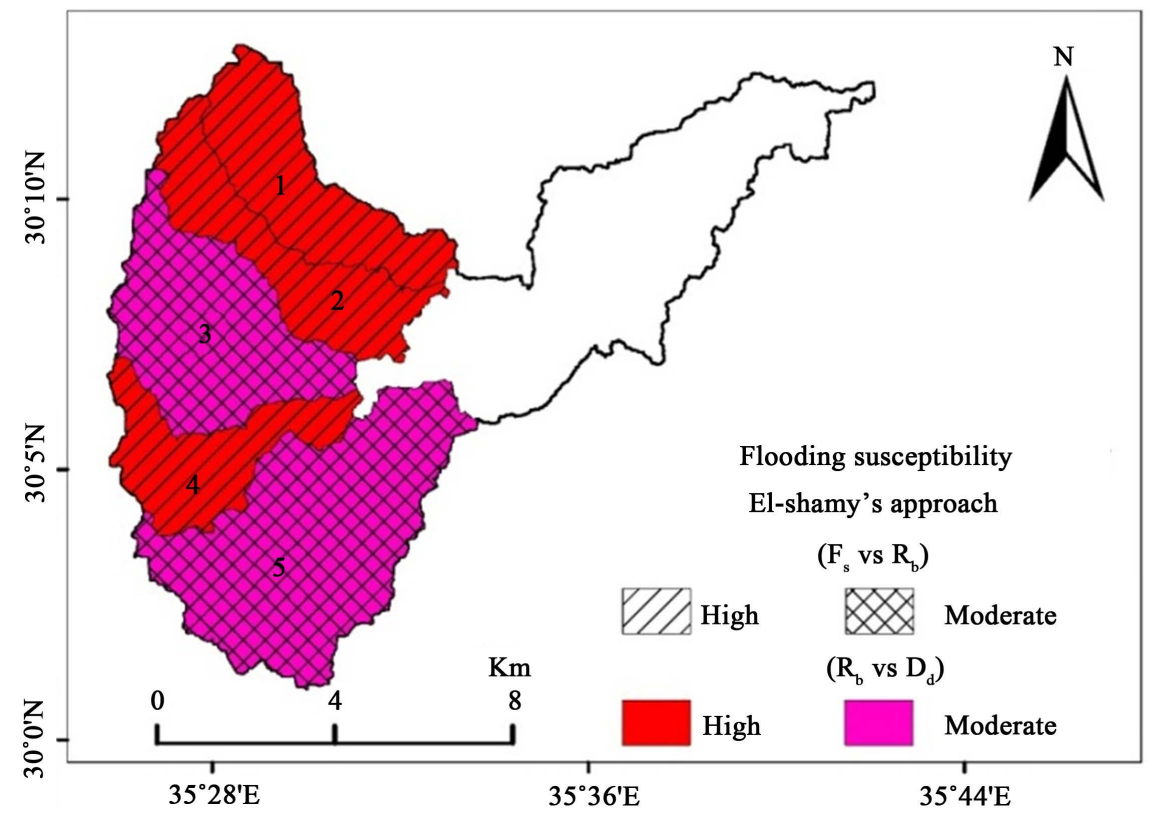

Figure 9. Flooding susceptibility of W. Wuheida based on El-Shamy's approach ( $R_{b}$ vs. $\left.D_{d}\right)$ layer superimposed on $\left(R_{b}\right.$ vs. $\left.F_{s}\right)$ layer. 
flash flood susceptibility by use of El-Shamy's approach as clarified through sub-basins categorized under zone $(A)$ and zone $(C)$ for W. Rajil, and zone $(B)$ and zone $(A)$ for W. Wuheida.

\subsection{The Morphometric Hazard Degree for Flash Floods Assessment Method}

The Morphometric Hazard Degree assessment method was employed to perform the required morphometric analysis, to estimate the flash flood hazard and the degree of risk for the sub-basins of W. Rajil and W. Wuheida, Table 7 and Table 8 display the results of this method for both watersheds, as expressed by ranking score for the different eleven morphometric parameters based on the relation with hazard whether proportional or inverse. To compile the flood risk map using GIS, the summation of hazard degree values for the sub-basins was grouped into five categories of susceptibility for flash floods as follows:
1) Low flooding susceptibility
$19-23.9$
2) Moderate flooding susceptibility
$24-27.9$
3) High flooding susceptibility
$28-31.9$
4) Very high flooding susceptibility
$32-35.9$
5) Extreme flooding susceptibility
$36-39.9$

Table 7. Hazard degrees of the effective parameters of the studied 16sub-basins of W. Rajil.

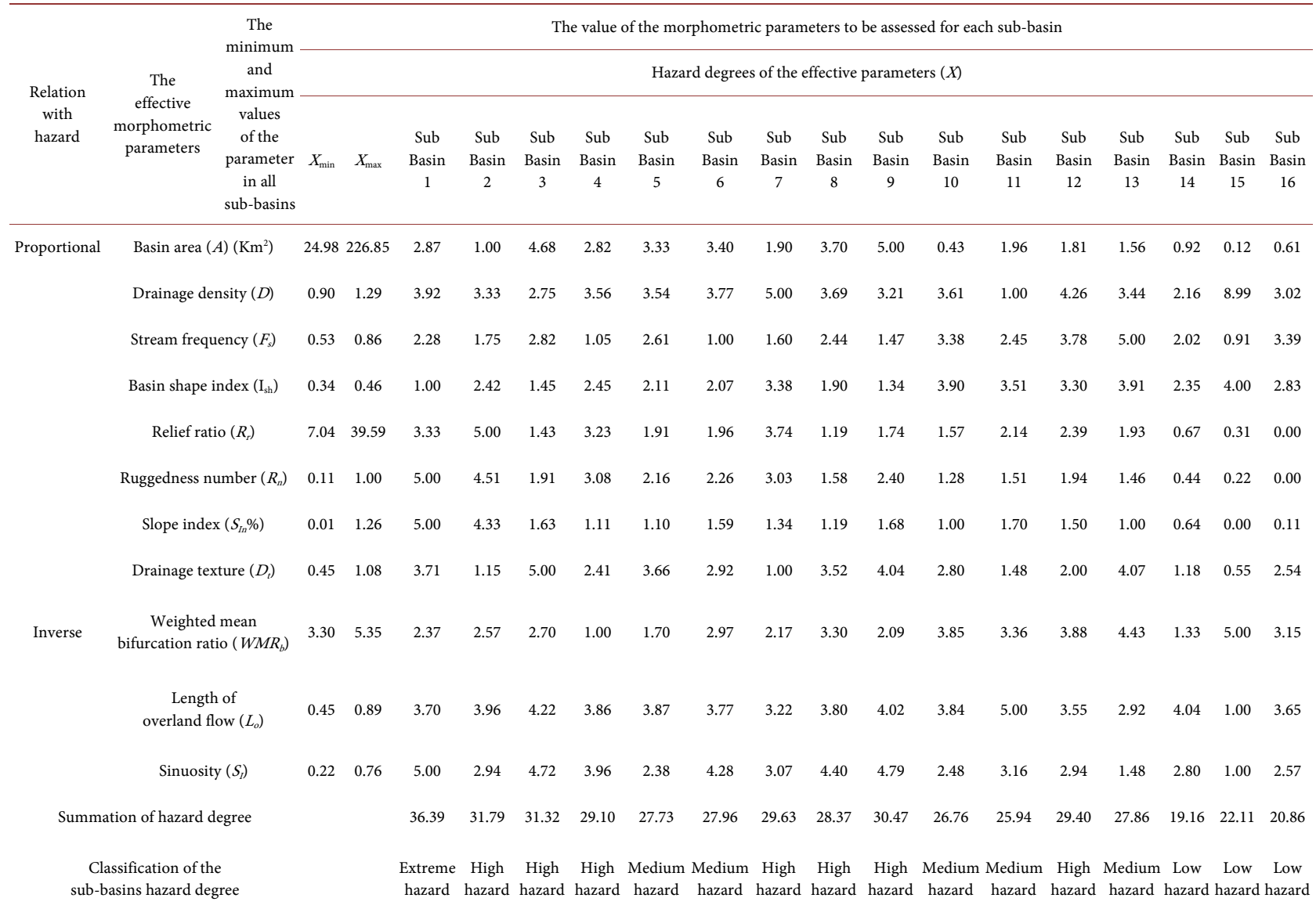


Table 8. Hazard degrees of the effective parameters of the studied 5 sub-basins of W. Wuhida.

\begin{tabular}{|c|c|c|c|c|c|c|c|c|c|}
\hline \multirow[t]{3}{*}{$\begin{array}{c}\text { Relation } \\
\text { with hazard }\end{array}$} & \multirow{3}{*}{$\begin{array}{c}\text { The } \\
\text { effective }\end{array}$} & \multirow{3}{*}{$\begin{array}{l}\text { The minimum } \\
\text { and maximum } \\
\text { values of the } \\
\text { parameter in all } \\
\text { sub-basins }\end{array}$} & \multicolumn{7}{|c|}{$\begin{array}{l}\text { The value of the morphometric parameters } \\
\text { to be assessed for each sub-basin }\end{array}$} \\
\hline & & & \multicolumn{7}{|c|}{ Hazard degrees of the effective parameters $(X)$} \\
\hline & & & $X_{\min }$ & $X_{\max }$ & $\begin{array}{c}\text { Sub } \\
\text { Basin } 1\end{array}$ & $\begin{array}{c}\text { Sub } \\
\text { Basin } 2\end{array}$ & $\begin{array}{c}\text { Sub } \\
\text { Basin } 3\end{array}$ & $\begin{array}{c}\text { Sub } \\
\text { Basin } 4\end{array}$ & $\begin{array}{c}\text { Sub } \\
\text { Basin } 5\end{array}$ \\
\hline \multirow[t]{8}{*}{ Proportional } & Basin area $(A)\left(\mathrm{Km}^{2}\right)$ & & 21.43 & 59.22 & 1.64 & 1.38 & 2.76 & 1.00 & 5.00 \\
\hline & Drainage density $(D)$ & & 1.77 & 2.04 & 1.64 & 1.00 & 2.13 & 5.00 & 1.87 \\
\hline & Stream frequency $\left(F_{s}\right)$ & & 1.68 & 2.28 & 2.65 & 1.01 & 1.37 & 2.86 & 5.00 \\
\hline & Basin shape index $\left(I_{s h}\right)$ & & 0.42 & 0.48 & 3.97 & 4.36 & 2.68 & 5.00 & 1.00 \\
\hline & Relief ratio $\left(R_{r}\right)$ & & 25.04 & 47.59 & 5.00 & 4.87 & 2.44 & 4.07 & 1.00 \\
\hline & Ruggedness number $\left(R_{n}\right)$ & & 0.61 & 0.75 & 5.00 & 3.01 & 1.72 & 2.03 & 1.00 \\
\hline & Slope index $\left(S_{I n} \%\right)$ & & 0.14 & 0.27 & 2.72 & 2.15 & 5.00 & 1.00 & 1.18 \\
\hline & Drainage texture $\left(D_{t}\right)$ & & 0.93 & 2.47 & 2.18 & 1.00 & 2.83 & 1.39 & 5.00 \\
\hline \multirow[t]{3}{*}{ Inverse } & $\begin{array}{c}\text { Weighted mean } \\
\text { bifurcation ratio }\left(W M R_{b}\right)\end{array}$ & & 4.09 & 5.23 & 5.00 & 2.20 & 1.00 & 2.20 & 3.14 \\
\hline & Length of overland flow $\left(L_{o}\right)$ & & 0.89 & 1.02 & 4.36 & 5.00 & 3.87 & 1.00 & 4.13 \\
\hline & Sinuosity $\left(S_{I}\right)$ & & 0.26 & 1.95 & 3.68 & 5.00 & 4.20 & 1.00 & 3.62 \\
\hline \multicolumn{2}{|c|}{ Summation of hazard degree } & & & & 37.85 & 30.97 & 29.99 & 26.55 & 31.94 \\
\hline \multicolumn{2}{|c|}{ Classification of the sub-basins hazard degree } & & & & $\begin{array}{l}\text { Extreme } \\
\text { hazard }\end{array}$ & $\begin{array}{l}\text { High } \\
\text { hazard }\end{array}$ & $\begin{array}{l}\text { High } \\
\text { hazard }\end{array}$ & $\begin{array}{c}\text { Moderate } \\
\text { hazard }\end{array}$ & $\begin{array}{c}\text { High } \\
\text { hazard }\end{array}$ \\
\hline
\end{tabular}

With respect to the sixteen sub-basins of W. Rajil watershed, sub-basins nos. 14,15 , and 16 (18.75\% of the total) have the lowest overall values, therefore representing the category of low flooding susceptibility (Table 7 and Figure 10). Sub-basins nos. $13,11,10,6$, and 5 (37.5\% of the total) have intermediate score values, thus characterized by moderate flooding susceptibility. Conversely, sub-basins nos. $12,9,8,7,4,3$, and 2 (43.75\% of the total) have high overall score values, and thus represent relatively dangerous sub-basins with high flooding susceptibility. Additionally, sub-basin no. 1 has the highest overall score value, thus, representing the most dangerous sub-basins with extreme flooding susceptibility (Figure 10). None of the sub-basins of W. Rajil is classified as of very high flooding susceptibility. It can be concluded that $50 \%$ of W. Rajil sub-basins are expected to suffer high and extreme flooding susceptibility. It can also be deduced that $81.25 \%$ of W. Rajil sub-basins are expected to experience moderate, high, and extreme susceptibility to flooding. Such results reveal that the main hazardous sub-basins are located on the northwest and eastern parts of the watershed, and directly threaten the lower part leading to Qa'a Azraq, Azraq town, wetland reserve, Azraq-Safawi and the Azraq-Qrayyat (to Saudi Arabia), major roads seriously threatened by expected flooding. Thus, the protection of the town, agricultural areas, and, the major roads from repetitive 


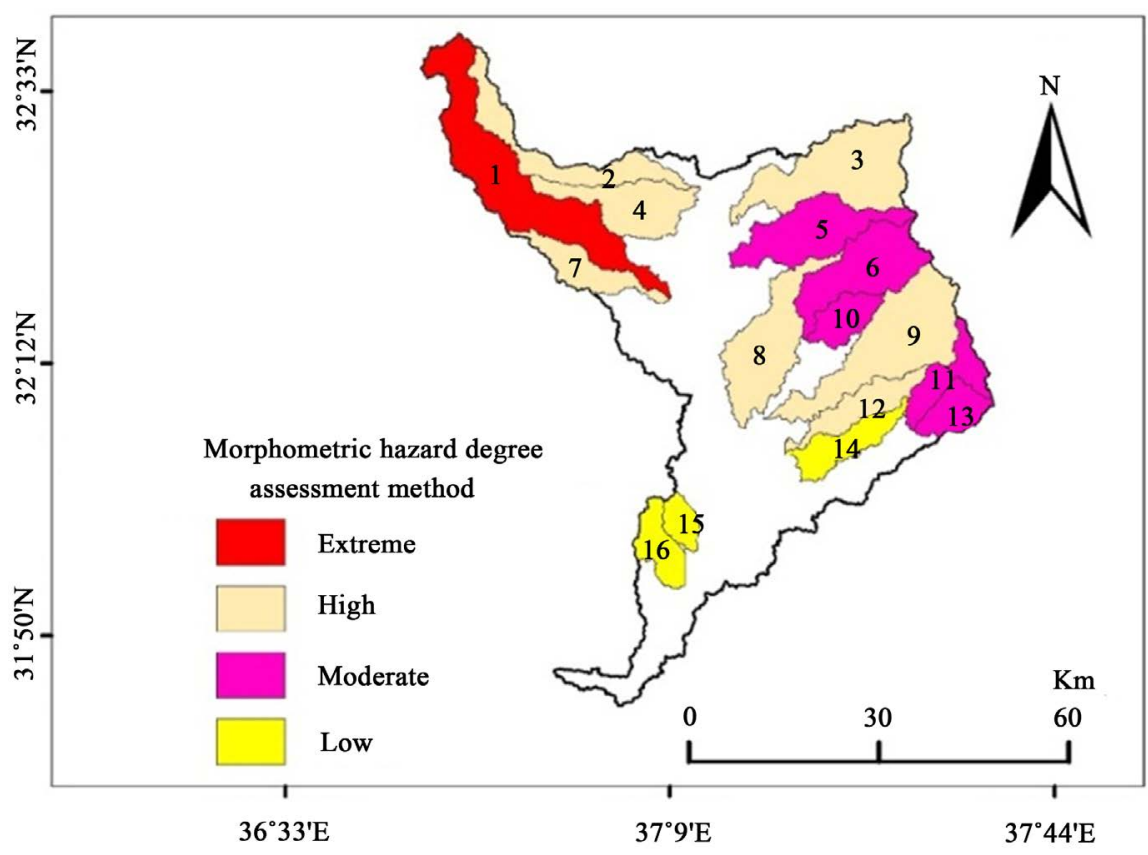

Figure 10. Sub-basins flooding hazard degree of W. Rajil based on the morphometric hazard degree assessment method.

flooding is essential to maintain future development of the Azraq area as a tourism and environmental conservation center.

With respect to the five sub-basins of W. Wuheida, the summation of the hazard degree scores for the sub-basins of the watershed, was grouped into five categories of susceptibility for flash floods such as the following:

1) Low flooding susceptibility

$20-23.9$

2) Moderate flooding susceptibility

$24-27.9$

3) High flooding susceptibility

$28-31.9$

4) Very high flooding susceptibility

$32-35.9$

5) Extreme flooding susceptibility

$36-39.9$

Accordingly, sub-basin no. 1 of W. Wuheida ( $20 \%$ of the total) has the highest overall score values: it thus, represents extreme flooding susceptibility (Table 8 and Figure 11). Whereas sub-basins nos. 2, 3, and 5 (60\% of the total) have high score values and are thus, characterized by high flooding susceptibility. Alternatively, sub-basin no. 4 (20\% of the total) has an intermediate score value, hence it represents moderate flooding susceptibility. It is obvious that $80 \%$ of Wadi $\mathrm{Wu}$ heida sub-basins are of extreme and high flooding susceptibility. Sub-basins nos. $1,2,3$, and 5 are the most hazardous sub-basins, and are located within the headwaters of W. Wuheida in a mushroom-like shape (Figure 11). This zone is directly affected by the track of depressions which approach the catchment either from the west to east (frontal storms) or form southwest to northeast (Red Sea Trough storms). Furthermore, the mushroom shape provides a larger headwater area (56\% of the total watershed area), which comprises the highest terrain in Ras En Naqb/Sharah highlands, with an average annual rainfall 


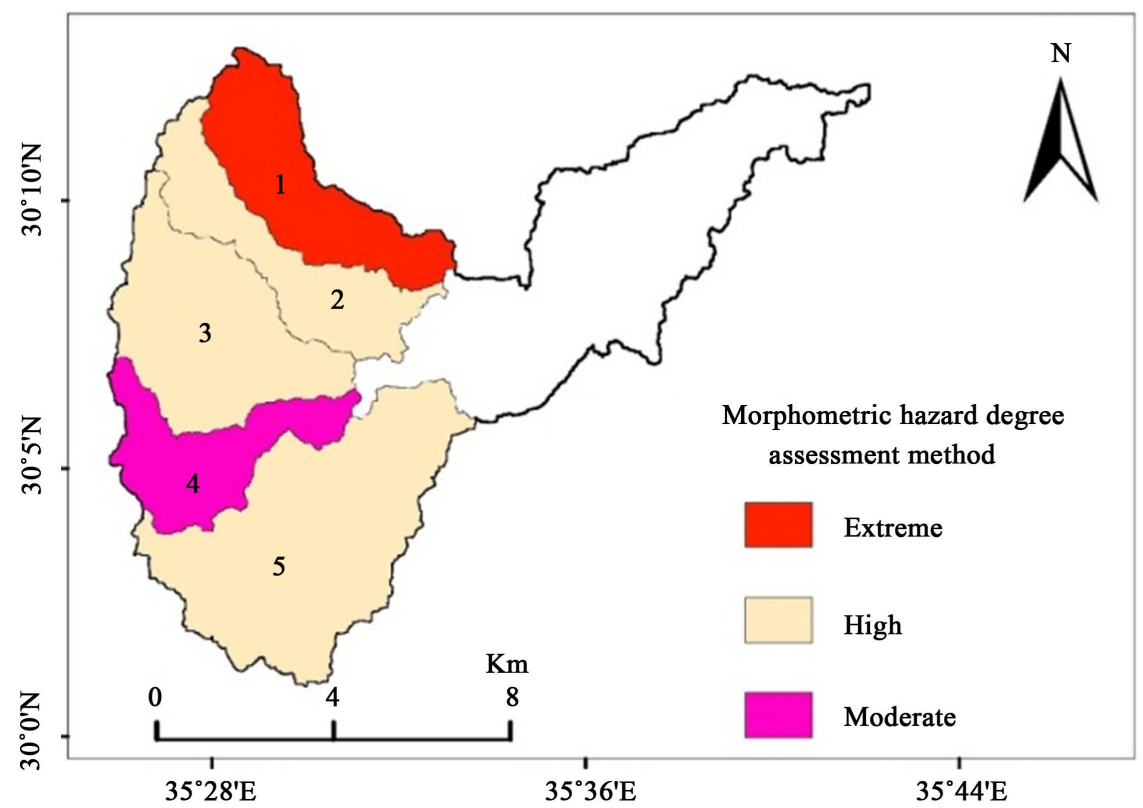

Figure 11. Sub-basins flooding hazard degree of W. Wuheida based on the morphometric hazard degree assessment method.

approaching $160 \mathrm{~mm}$, since this area receives the highest precipitation, and recorded repetitive destructive floods associated with high slopes yielding high runoff potential [17]. The extreme flood of W. Wuheida on 11 March 1966 (or Ma'an flood), and the major flood of 2 - 3 February 2006 resulted in high peak discharge, estimated at $540 \mathrm{~m}^{3} / \mathrm{s}$ for WadiYutum south of Ras En Naqb [7] [8], and 270 to $320 \mathrm{~m}^{3} / \mathrm{s}$ for W. Wuheida, north of Ras En Naqb/Sharah, during the 2006 flood [17].

Consequently, Ma'an city, El-Jafr playa, local inhabitants in the upper reaches of the watershed, and the Amman-Aqaba highway are seriously threatened by destructive flash floods. For this reason, flood control in the upper catchment is highly requisite to protect $\mathrm{Ma}$ 'an city and other infrastructure facilities against flooding in order to maintain future development of the Ma'an-Ras En Naqb area.

\section{Conclusions}

In the present study, hydro-morphometric analysis, and GIS-based flood hazard and flood susceptibility mapping were carried out to display flood-prone areas in W. Rajil and W. Wuheida catchments. Flood risk analysis was conducted using two morphometric analysis methods within a GIS environment. These methods are 1): El-Shamy's approach; and 2): the morphometric hazard degree for flash flood assessment method. Sub-basins affected by floods of low, moderate, high, very high, or extreme flooding susceptibility can be demarcated. Consistent results were achieved on flash flood susceptibility utilizing El-Shamy's approach as illustrated through sub-basins categorized under zone $(A)$ and zone $(C)$ for W. Rajil; and zone $(A)$ and zone $(B)$ for W. Wuheida. In this regard, sub-basins nos. 
1, 3, 5 and 9 of W. Rajil are ranked under low susceptibility for flash floods based on the relation between $R_{b}$ vs. $D_{d}$ and $R_{b}$ vs. $F_{s}$. Similarly, sub-basins nos. 7, 10, $11,12,14,15$, and 16 are categorized under high susceptibility for flash floods based on both previous relations (except sub-basins no.6 and 4). Reasonable results were obtained for W. Wuheida. Sub-basin no. 1 was ranked under an extreme susceptibility for flash floods, and sub-basin 4 was grouped under the class of moderate susceptibility for flash floods based on both relations between $R_{b}$ vs. $D_{d}$ and $R_{b}$ vs. $F_{s}$. The superimposition of the two thematic layers of El-Shamy's approach, $R_{b}$ vs. $F_{s}$ layer, and $R_{b}$ vs. $F_{s}$ layer for both W. Rajil showed that sub-basins $7,10,11,12,14,15$, and 16 (44\% of the total) are grouped under high possibility of flash flood on both relations. With reference to $\mathrm{W}$. Wuheida, sub-basins 1, 2, and 4 (75\% of the total) are classified under the category of high susceptibility for flash floods. None of the sub-basins are ranked in the category of low susceptibility for flash floods. The results of the morphometric hazard degree for flash floods assessment method indicate that $50 \%$ of W. Rajil sub-basins are expected to suffer high and extreme flooding susceptibility. Thus, it is anticipated that $81.25 \%$ of W. Rajil sub-basins will likely experience moderate, high, and extreme susceptibility for flooding. Such results reveal that the main hazardous sub-basins are located on the northwestern and eastern part of the watershed, and directly threaten the lower part leading to Qa'a Azraq, the Azraq town, wetland reserve, Azraq-Safawi, and Azraq-Qrayyat (to Saudi Arabia), major roads seriously threatened by expected flooding. As far as W. Wuheida is concerned, $80 \%$ of sub-basins nos. 1, 2, 3, and 5 are of extreme and high flooding susceptibility. These sub-watersheds receive the highest rainfall (160 $\mathrm{mm}$ annually), and are characterized by moderate to relatively steep slopes. Thus, it yields high runoff potential. Repetitive destructive floods were recorded in W. Wuheida, and resulted in the destruction half of Ma'an town in 1966 due to high peak discharge. During the extreme flood, the estimated peak discharge of W. Yutum, south of Ras En Naqb was $540 \mathrm{~m}^{3} / \mathrm{s}$. Similarly, the peak discharge of W. Wuheida during the major flood of February 2006 was estimated in the range of 270 to $320 \mathrm{~m}^{3} / \mathrm{s}$. Based on the present results, it can be concluded that $81.25 \%$ of the sub-basins related to $\mathrm{W}$. Rajil can be categorized under moderate, high, and extreme susceptibility for flash floods. In parallel, $80 \%$ of the sub-basins pertaining to $\mathrm{W}$. Wuheida are grouped under high and extreme flooding susceptibility. Consequently, Ma'an city, the Amman-Aqaba highway, El-Jafr village, Qa'a Azraq, the Azraq town, wetland reserve, and major roads connecting Jordan with northern Saudi Arabia and western Iraq via Azraq are seriously exposed to flash floods. Thus, protection measures are highly requisite to protect Ma'an city, Azraq town, the Amman-Aqaba highway, other major roads, and infrastructure facilities against flooding, in order to maintain the future development of Ma'an and Azraq areas. Hydro-morphometric and GIS-based flood hazard and the generated flooding risk maps aim to help planners and decision makers to assess the potential impact of floods, and to avoid; areas exposed to harmful flash floods; and also to predict sites which are likely to 
be flooded in the future. Decision makers can also act properly pre-disaster, during, and post-disaster; thus, precautionary measures can be prepared in order to minimize flooding effects. Post-disaster, the compiled GIS maps can also help decision makers to assess damage and losses caused by flooding. Therefore, flood protection measures can be usefully implemented to protect developed sites against flooding.

\section{References}

[1] Abrahams A.D. (1984) Channel Networks: A Geographical Perspective. Water Resources Research, 20, 161-168. https://doi.org/10.1029/WR020i002p00161

[2] IAHS-UNESCO-WMO (1974) Flash Floods. Proceedings of the Paris Symposium, Publication no. 112.

[3] Esper Angillieri, M.Y. (2008) Morphometric Analysis of Colangüil River Basin and Flash Flood Hazard, San Juan, Argentina. Environmental Geology, 55, 107-111. https://doi.org/10.1007/s00254-007-0969-2

[4] NSW/NOAA. (2010) Glossary. (Accessed 1.10.2015). http://www.weather.gov/glossary/

[5] Youssef, A.M., Pradhan, B., Gaber, A.F.D. and Buchriothner, M.F. (2009) Geomorphological Hazard Analysis along the Egyptian Red Sea Coast between Safaga and Quseir. Natural Hazard and Earth System Sciences, 9, 751-766. https://doi.org/10.5194/nhess-9-751-2009

[6] Xiao, L. (1999) Flash Floods in Arid and Semi Arid Zones. International Hydrological Program. Technical Documents in Hydrology No. 23 UNESCO, Paris.

[7] Central Water Authority, Hydrologic Division (1966) Floods in Southern Jordan on 11 March 1966. Unpublished Report, Amman.

[8] Schick, A. (1971) A Desert Flood: Physical Characteristics, Effect on Man, Geomorphic Significance, Human Adaptation: A Case Study in the Southern Arava Watershed. Jerusalem Studies in Geography, 2, 91-155.

[9] Schick, A., Grodek, T. and Wolman, M.G. (1999) Hydrologic Processes and Geomorphic Constraints on Urbanization of Alluvial Fan Slopes. Geomorphology, 31, 325-335. https://doi.org/10.1016/S0169-555X(99)00085-9

[10] Grodek, J., Lekach, J. and Schick, A. (2000) Urbanizing Alluvial Fans as Flood-Conveying and Flood-Reducing System: Lessons from the October 1997 Eilat Flood. In: Hassan, M., Ed., The Hydrology-Geomorphology Interface: Rainfall, Floods, Sedimentation, Land Use, International Association of Hydrological Sciences Publication, No. 261, 229-250.

[11] Farhan, Y. and Anbar, A. (2014) Fragile Landscape: Impact and Consequences of May 2014 Flash-Flood Disaster in the Aqaba Area, Southern Jordan. Research Journal of Environmental and Earth Science, 6, 451-465.

[12] Abdel-Lattif, A. and Sherief Y. (2012) Morphometric Analysis and Flash Floods of Wadi Sudr and Wadi Wardan, Gulf of Suez, Egypt: Using Digital Elevation Model. Arab Journal of Geosciences, 5, 181-195. https://doi.org/10.1007/s12517-010-0156-8

[13] Elmoustafa, A. and Mohamed, M. (2013) Flash Flood Risk Assessment Using Morphological Parameters in Sinai Peninsula. Open Journal of Modern Hydrology, 3, 122-129. https://doi.org/10.4236/ojmh.2013.33016

[14] Youssef, A.M., Pradhan, B. and Sefry, S. (2016) Flash Flood Susceptibility Assessment in Jedda City (Kingdom of Saudi Arabia) Using Bivariate and Multivariate 
Statistical Models. Environmental Earth Sciences, 75, 1-16. https://doi.org/10.1007/s12665-015-4830-8

[15] Farhan, Y. (1989) Urban Planning and Flood Hazard Assessment in Arid Regions, Case Study: Aqaba Region. In: Farhan, Y., Behery, S. and Abu Safat, M., Eds., Geomorphological Studies on Southern Jordan, Publication of the University of Jordan, 181-206. (In Arabic)

[16] Al-Weshah, R. and El-Khoury, F. (1999) Flood Analysis and Mitigation for Petra Area in Jordan. Journal of Water Resources Planning and Management, 125, 170-177. https://doi.org/10.1061/(ASCE)0733-9496(1999)125:3(170)

[17] Al-Qudah, K.A. (2011) Floods as Water Resource and as a Hazard in Arid Regions: a Case study in Southern Jordan. Jordan Journal of Civil Engineering, 5, 148-161.

[18] Farhan, Y. (2014) Geomorphological Evaluation for Urban Development Using Remote Rensing and GIS, Southern Coast of Aqaba, Jordan. Journal of Environmental and Earth Sciences, 3, 104-118.

[19] Farhan, Y. (1999) Geomorphic Impacts of Highway Construction, Their Causes and Remedies: A Case Study from Aqaba, Southern Jordan. Arab World Geographer, 2, 1-25.

[20] Horton, R. (1945) Erosional Development of Streams and Their Drainage Basins: Hydrological Approach to Quantitative Morphology. Geological Society of America Bulletin, 56, 275-370. https://doi.org/10.1130/0016-7606(1945)56[275:EDOSAT]2.0.CO;2

[21] Strahler, A. (1952) Dynamic Basis of Geomorphology. Geological Society of America Bulletin, 63, 938. https://doi.org/10.1130/0016-7606(1952)63[923:DBOG]2.0.CO;2

[22] Strahler, A. (1954) Statistical Analysis in Geomorphic Research. Journal of Geology, 62, 1-25. https://doi.org/10.1086/626131

[23] Strahler, A. (1957) Quantitative Analysis of Watershed Geomorphology. Transactions, American Geophysical Union, 38, 913-920. https://doi.org/10.1029/TR038i006p00913

[24] Strahler, A. (1964) Quantitative Geomorphology of Drainage Basin and Channel Networks. In: Chow, V.T., Ed., Handbook of Applied Hydrology. McGraw Hill, New York.

[25] Schumm, S. (1956) Evolution of Drainage Systems and Slopes in Badlands at Perth Amboy, New Jersey. Geological Society of America Bulletin, 67, 597-646. https://doi.org/10.1130/0016-7606(1956)67[597:EODSAS]2.0.CO;2

[26] Smith, K. (1958) Erosional Processes and Landforms in Badlands, National Monument, South Dakota. Geological Society of America Bulletin, 69, 975-1008. https://doi.org/10.1130/0016-7606(1958)69[975:EPALIB]2.0.CO;2

[27] El-Shamy, I. (1992) Recent Recharge and Flash Flooding Opportunities in the Eastern Desert, Egypt. Annals of Geological Survey of Egypt, 18, 323-334.

[28] Davis, J.C. (1975) Statistics and Data Analysis in Geology. Wiley, New York.

[29] Sewidan, A.S. (2000) (MORPHOMET \& HRZARD) Computer Program of Morphometric Parameters and Basins Hazard Degrees Calculations, Infiltration Test Calculation, Hydrology Department. Desert Research Center, Cairo, Egypt.

[30] Yousif, M. and Bubenzer, O. (2015) Geoinformatics Application for Assessing the Potential of Rainwater Harvesting in Arid Regions. Case Study: El Daba'a Area, Northwestern Coast of Egypt. Arab Journal of Geosciences, 9, 9169-9191. https://doi.org/10.1007/s12517-015-1837-0 
[31] Baker, V.R., Kochel, R.C. and Patton, P.C. (1988) Flood Geomorphology. Wiley, New York.

[32] Cooke, R.U., Brunsden, D., Doornkamp, J.C. and Jones, D.K.C. (1985) Urban Geomorphology in Dry Lands. Oxford University Press, New York.

[33] Golany, G. (1983) Planning Principles of Arid-Zone Settlement. Habitat International, 7, 147-163. https://doi.org/10.1016/0197-3975(83)90042-5

[34] Peng, S.H., Shieh, M. and Fan, S. (2010) Potential Hazard Map for Disaster Prevention Using GIS Base Linear Combination Approach and Analytic Hierarchy Method. Journal of Geographic Information System, 4, 403-411. https://doi.org/10.4236/jgis.2012.45046

[35] Nkeki, F.N., Henah, P.H. and Ojeh, V.N. (2013) Geospatial Technique for the Assessment and Analysis of Flood Risk Along the Niger-Benue Basin in Nigeria. Journal of Geographic Information System, 5, 123-135. https://doi.org/10.4236/jgis.2013.52013

[36] Abed, A.M. (2000) Geology of Jordan, its Environment and Water. Jordan Geological Association, Amman. (In Arabic)

[37] Quennell, A. (1958) The Structure and Geomorphic Evolution of the Dead Sea Rift. Quarterly Journal of the Geological Society, 114, 1-24. https://doi.org/10.1144/gsigs.114.1.0001

[38] Bender, F. (1974) Geology of Jordan, Khdeir, M.K. Trans. Beiträgezürregionalen Geologie der Erde, 7, Gebrüder, Borntraeger, Berlin.

[39] Water Authority of Jordan (1990) Water Resources Study of the Jafr Basin, JICA.

[40] Abu Hussein, A.S. (1994) The Effect of the Red Sea Trough on Jordan Climate during the Fall and Spring Seasons. Unpublished Master's Dissertation, University of Jordan, Amman.

[41] Jordan Meteorological Department (JMD) (2008) Climatic Data Bank, Amman.

[42] Natural Resources Authority (NRA) (1992) The Geology of the Azraq Basin. Internal Report of NRA, Amman, Jordan.

[43] Ta'any, R. (2013) Availability of Surface Water of Wadi Rajil as a Source of Groundwater Artificial Recharge: A Case Study of Eastern Badia/Jordan. Current World Environment, 8. http://doi.org./10.12944/CWE.8.2.04

[44] Al-Fugara, A. (2015) Comparison and Validation of the Recent Freely Available DEM's over Part of the Earth's Lowest Elevation Area: Dead Sea, Jordan. International Journal of Geosciences, 6, 1221-1232. https://doi.org/10.4236/ijg.2015.611096

[45] ASTER DEM Validation Team (2014) Global Digital Elevation Model Version 2 -Summary and Validation Results.

https://www.jspace-systems.org.jp/ersdac/GDEM/ver2validatioin/summaryGDEM2 validationreport-final.Pdf

[46] Miller, V. (1953) A Quantitative Geomorphic Study of Drainage Basin Characteristics in the Clinch Mountain Area, Virginia and Tennessee. Project NR389-402, Technical Report 3, Columbia University, Department of Geology, ONR, New York.

[47] Youssef, A.,M., Pradhan, B. and Hassan, A.M. (2011) Flash flood Risk Estimation Along the St. Katherine Road, Southern Sinai, Egypt Using GIS Based Morphometry and Satellite Imagery. Environmental Earth Sciences, 62, 911-623. https://doi.org/10.1007/s12665-010-0551-1

[48] Wahid, A., Madden, M., Khalaf, F. and Fathy, I. (2016) Geospatial Analysis for the Determination of Hydro-Morphological Characteristics and Assessment of Flash 
Flood Potentiality in Arid Coastal Plains: A Case in Southern Sinai, Egypt. Earth Science Research Journal, 20, E1-E9. https://doi.org/10.15446/esrj.v20n1.49624

[49] Perucca, L.P. and Esper Angillieri, Y. (2011) Morphometric Characterization of del Molle Basin Applied to the Evaluation of Flash Floods Hazard, Iglesia Department, San Juan, Argentina. Quaternary International, 233, 81-86. https://doi.org/10.1016/j.quaint.2010.08.007

[50] Shi, Q. (2014) Flood Hazard Assessment along the Western Regions of Saudi Arabia Using GIS-Based Morphometry and Remote Sensing Techniques. MSc Thesis, King Abdullah University of Science and Technology, Thuwal, Kingdom of Saudi Arabia.

[51] Bajabaa, S., Masoud, M. and Al-Amri, N. (2013) Flash Flood Hazard Mapping Based on Quantitative Hydrology, Geomorphology and GIS Techniques (Case Study of Wadi Al Lith, Saudi Arabia). Arab Journal of Geosciences, 7, 2469-2481. https://doi.org/10.1007/s12517-013-0941-2

[52] Bender, F. (1975) Geology of the Arabian Peninsula: Jordan. United States Geological Survey Professional Paper 450-I.

[53] Al-Saady, Y., Al-Suhail, Q., Al-Tawash, B., Othman A. (2016) Drainage Network Extraction and Morphometric Analysis Using Remote Sensing and GIS Mapping Techniques (Lesser Zab River Basin, Iraq and Iran). Environmental Earth, Sciences, 75, 1243. https://doi.org/10.1007/s12665-016-6038-y

[54] Chorley, R., Donald, M. and Pogrzelski, H. (1957) A New Standard for Estimating Drainage Basin Shape. American Journal of Science, 255, 138-141.

https://doi.org/10.2475/ajs.255.2.138

[55] Sreedevi, P.D., Sreekanth, P.D., Khan, H.H. and Ahmad, S. (2013) Drainage Morphometry and its Influence on Hydrology in a Semi Arid Region: Using SRTM Data and GIS. Environmental Earth Sciences, 70, 839-848. https://doi.org/10.1007/s12665-012-2172-3

[56] Strahler, A. (1953) Revision of Hortons' Quantitative Factors in Erosional Terrain. Transactions, American Geophysical Union, 34, 345-365.

[57] Sreedevi, P.D., Subrahmanyan, K. and Shakkel, A. (2005) The Significance of Morphometric Analysis for Obtaining Groundwater Potential Zones in a Structurally Controlled Terrain. Environmental Geology, 47, 412-420. https://doi.org/10.1007/s00254-004-1166-1

[58] Wolman, M.G. and Miller, J.P. (1960) Magnitude and Frequency of Forces in Geomorphic Process. Journal of Geology, 68, 54-74. https://doi.org/10.1086/626637

[59] Mesa, L.M (2006) Morphometric Analysis of a Subtropical Andean Basin (Tucumán, Argentina). Environmental Geology, 50, 1235-1242. https://doi.org/10.1007/s00254-006-0297-y

[60] Verstappen, H.Th. (1983) Applied Geomorphology-Geomorphological Surveys for Environmental Development. Elsevier, New York.

[61] Thomas, J., Joseph, S., Thrivikramji, K.P., Abe, G., and Kannan, N. (2012) Morphometric Analysis of Two Tropical Mountain River Basins of Contrasting Environmental Setting, the South Western Ghats, India. Environmental Earth Sciences, 66, 2353-2366. https://doi.org/10.1007/s12665-011-1457-2

[62] Prasad, R., Mondal, N., Banerjee, P., Nadakumar, M. and Singh, V. (2008) Deciphering Potential Groundwater Zone in Hard Rock through the Application of GIS. Environmental Geology, 55,467-475. https://doi.org/10.1007/s00254-007-0992-3

[63] Magesh, N.S., Chandrasekar, N. and Soundranayagam, J.P. (2011) Morphometric Evaluation of Papanasam and Manimuthar Watersheds, Part of Western Ghats, Ti- 
runelueli District, Tamil Nadu, India: A GIS approach. Environmental Earth Sciences, 64, 374-381. https://doi.org/10.1007/s12665-010-0860-4

[64] Smith, K. (1950) Standards for Grading Textures of Erosional Topography. American Journal of Science, 248, 655-668. https://doi.org/10.2475/ajs.248.9.655

[65] Farhan, Y. (2017) Morphometric Assessment of Wadi Wala Watershed, Southern Jordan Using ASTER (DEM) and GIS. Journal of Geographic Information System, 9, 158-190. https://doi.org/10.4236/jgis.2017.92011

[66] Patton, P. and Baker, V. (1976) Morphometry and Floods in Small Drainage Basis Subject of Driverse Hydrogeomorphic Controls. Water Resources Research, 12, 941-952. https://doi.org/10.1029/WR012i005p00941

[67] Sujatha, E., Selvakumar, R., Rojasimman, U. and Victor, R. (2013) Morphometric Analysis of Sub-Watersheds in Part of Western Ghats, South India Using ASTER DEM. Geomatics, Natural Hazards and Risk, 6, 326-341. https://doi.org/10.1080/19475705.2013.845114

[68] Singh, S, and Singh, M.C. (1997) Morphometric Analysis of Kanhar River Basin. National Geographical Journal of India, 43, 31-43.

[69] Gregory, K.J. and Walling, D. E. (1973) Drainage Basin Form Process. Wiley, New York.

[70] Haggett, P. (1965) Locational Analysis in Human Geography, Edward Arnold Ltd, London.

[71] Majuri, J.J. and Soenksen, P.J. (1991) Using a Geographical Information System to Determine Physical Basin Characteristics for Use in Flood-Frequency Equations. In: Balthrop, B.H. and Terry, J.E., Eds., U.S. Geological Survey National Computer Technology Meeting-Proceedings, Phoenix, Arizona, 14-18 November 1988, U.S. Geological Survey Water Resources Investigations Report 90-4162:31-40. 